\title{
Imidazole to NHC rearrangements at molybdenum centers. An experimental and theoretical study
}

\author{
Marcel Brill, ${ }^{\ddagger[a]}$ Jesús Díaz, ${ }^{*[b]}$ Miguel A. Huertos, ${ }^{[a]}$ Ramón López, ${ }^{*[c]}$ Julio Pérez, ${ }^{[a]}$ \\ and Lucía Riera**[d]
}

\begin{abstract}
Both manganese and rhenium complexes of the type $\left[\mathrm{M}(\text { bipy })(\mathrm{CO})_{3}(N \text {-RIm })\right]^{+} \quad$ undergo deprotonation of the central $\mathrm{CH}$ group of the $N$-alkylimidazole $(N$-RIm) ligand when treated with a strong base. However, the outcome of the reaction is very different for either metal. For Mn, the addition of the equimolar amount of an acid to the product of the deprotonation affords an NHC complex, whereas for $\mathrm{Re}$, once the deprotonation of the central imidazole $\mathrm{CH}$ group has occurred, the 2,2'-bipyridine ligand undergoes a nucleophilic attack on an ortho carbon, affording the $\mathrm{C}-\mathrm{C}$ coupling product. The extension of
\end{abstract}

these studies to pseudooctahedral $\left[\mathrm{Mo}\left(\eta^{3} \text {-allyl }\right)(\text { bipy })(\mathrm{CO})_{2}(N-\mathrm{RIm})\right]^{+}$ complexes has allowed us to isolate cationic NHC complexes (Mn(I)-type behavior), as well as their neutral imidazol-2-yl precursors. Theoretical studies of the reaction mechanisms using DFT computations were carried out on the deprotonation of $\left[\mathrm{Mn} \text { (bipy) }(\mathrm{CO})_{3}(\mathrm{~N}-\mathrm{PhIm})\right]^{+}$,

$\left[\operatorname{Re}(\text { bipy })(\mathrm{CO})_{3}(\mathrm{~N}-\mathrm{MesIm})\right]^{+}, \quad$ and $\left[\mathrm{Mo}\left(\eta^{3}-\mathrm{C}_{4} \mathrm{H}_{7}\right)(\text { bipy })(\mathrm{CO})_{2}(\mathrm{~N}-\mathrm{MesIm})\right]^{+}$ complexes at the B3LYP/6-31G(d) (LANL2DZ for Mn, Re, and Mo) level of theory. Our results explain why different products have been found experimentally for $\mathrm{Mn}$, Mo, and Re complexes. For Re, the process leading to a $\mathrm{C}-\mathrm{C}$ coupling product is clearly more favored than those forming an imidazol-2-yl product. In contrast, for $\mathrm{Mn}$ and Mo complexes, the lower stabilizing interaction between the central imidazole and ortho bipy $\mathrm{C}$ atoms, along with the higher lability of the ligands, make the formation of an NHC-type product kinetically more accessible, in good agreement with experimental findings.

Keywords: DFT calculations $\bullet$
imidazole $\bullet$ N-heterocyclic carbene
$\cdot$ molybdenum $\bullet$ reaction
mechanisms

\section{Introduction}

[a] M. Brill, Dr. M. A. Huertos, Dr. J. Pérez

Departamento de Química Orgánica e Inorgánica-IUQOEM,

Facultad de Química,

Universidad de Oviedo-CSIC, 33006 Oviedo (Spain)

[b] Dr. J. Díaz,

Departamento de Química Orgánica e Inorgánica,

Facultad de Veterinaria,

Universidad de Extremadura, 10071 Cáceres (Spain)

E-mail: jdal@unex.es

[c] Dr. R. López,

Departamento de Química Física y Analítica,

Facultad de Química,

Universidad de Oviedo, 33006 Oviedo (Spain)

E-mail: rlopez@uniovi.es

[d] Dr. L. Riera,

Instituto de Síntesis Química y Catálisis Homogénea (ISQCH), Departamento de Química Inorgánica,

CSIC-Universidad de Zaragoza, 50009 Zaragoza (Spain)

E-mail: riera@unizar.es

Supporting information for this article is available on the WWW under http://www.chemeurj.org/ or from the author.
$\mathrm{N}$-heterocyclic carbenes (NHCs) have become an intensively studied class of ligands, and their chemistry is one of the most active and exciting topics in synthesis and catalysis. ${ }^{[1]}$ Since the successful isolation of NHCs by Arduengo et. al., ${ }^{[2]}$ imidazole-based NHCs remain the ones most widely employed, and as a result, a large variety of their metal complexes are known. Methods for synthesizing these complexes mainly consist of direct reaction of free NHCs, either isolated or generated in situ, in turn produced by deprotonation of the corresponding imidazolium salts, with appropriate metal fragments. ${ }^{[3]}$ Manipulation of the free carbenes is often difficult due to their high reactivity, and therefore the development of new synthetic procedures for this kind of derivatives has attracted considerable interest in recent years. The employment of alcohol, chloroform or borane NHC adducts as protected forms has allowed the synthesis of metal complexes bearing these ligands. ${ }^{[4]}$ On the other hand, the use of $\mathrm{Ag}(\mathrm{I})$-NHC complexes as carbene transfer reagents is becoming a popular method for the synthesis of NHC complexes, especially for those of late transition metals. $^{[5]}$ 
An alternative route is the utilization of neutral $\mathrm{N}$ alkylimidazole $(N-\mathrm{RIm})$ ligands as precursors of NHCs [note that the $\mathrm{N}$-alkylimidazole term is widely used through the article being employed either for alkyl or arylimidazoles], although little is known about interconversion processes linking both types of ligands. ${ }^{[6,7]}$ In 2007 Ruiz and Perandones published the transformation of an imidazole $\mathrm{Mn}(\mathrm{I})$ compound into an NH-NHC complex by a deprotonation/protonation sequence (see Scheme 1a). ${ }^{[8]}$ About at the same time, we found that the deprotonation reaction of the analogous rhenium compounds, $\left[\operatorname{Re}(\right.$ bipy $)(\mathrm{CO})_{3}(\mathrm{~N}$ $\mathrm{RIm})] \mathrm{OTf}(\mathrm{R}=$ methyl, mesityl), lead to a completely different kind of products. ${ }^{[9]}$ As shown in Scheme $1 \mathrm{~b}$, the reaction of the rhenium species with a strong base deprotonated the imidazole $\mathrm{C} 2-\mathrm{H}$ group, and the so formed carbeniate attacked a $\mathrm{C}_{\text {ortho }}$ of the adjacent 2,2'bipyridine ligand. As a consequence, $\mathrm{C}-\mathrm{C}$ coupling and loss of aromaticity of the involved ring were observed.

a)

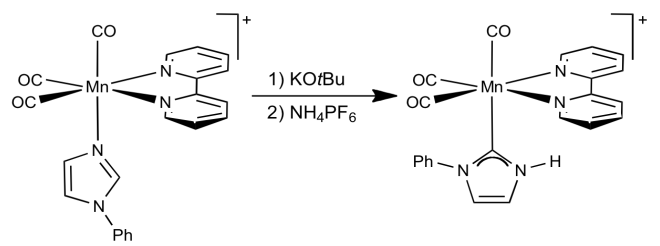

b)

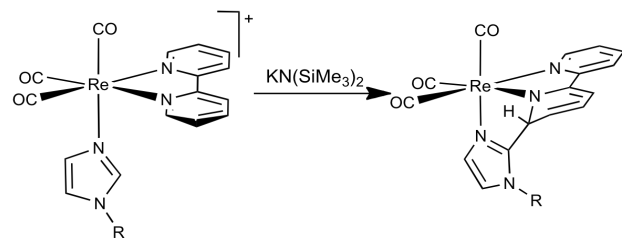

Scheme 1. Reactivity of $\left[\mathrm{M}(\right.$ bipy $\left.)(\mathrm{CO})_{3}(\mathrm{~N}-\mathrm{R} \operatorname{Im})\right]+(\mathrm{M}=\mathrm{Mn}, \mathrm{Re})$ compounds with a strong base.

Herein we report a density functional theory (DFT) study of the reactions of $\mathrm{Mn}$ and $\mathrm{Re}$ complexes aiming to understand the reasons of the dramatically different behavior found in the deprotonation of $\left[\mathrm{M}(\text { bipy })(\mathrm{CO})_{3}(\mathrm{~N}-\mathrm{RIm})\right]^{+}$compounds depending on the metal nature (Mn or Re). The intriguing located reaction mechanisms prompted us to extend our studies of deprotonation of $\mathrm{N}$-alkylimidazole ligands to Mo organometallic complexes because of its proximity to $\mathrm{Mn}$ and $\mathrm{Re}$ in the periodic table. Molybdenum (II) species were chosen because the substitution of a halide ligand by the $\mathrm{N}$ alkylimidazole affords cationic complexes, thus facilitating the deprotonation of the central $\mathrm{CH}$ group. The allyl complexes chosen feature, like those of $\mathrm{Mn}$ and Re compounds, pseudooctahedral structures in which the imidazole and each ring of the bipy ligand are in cis positions. The experimental results obtained with the molybdenum species are reported here for the first time, and have shown that the addition of a strong base to $\left[\mathrm{Mo}\left(\eta^{3}\right.\right.$ $\left.\mathrm{C}_{4} \mathrm{H}_{7}\right)$ (bipy)(CO) $\left.)_{2}(N-\mathrm{RIm})\right]^{+}$complexes, followed by protonation or alkylation of the resulting neutral product, leads to the formation of Mo-NHC compounds as found for the Mn(I) compounds. ${ }^{[8]}$ The theoretical calculations have shown that the reaction mechanism recently found for Mn complexes involving an initial attack onto a cis-CO ligand, ${ }^{[10]}$ is the preferred route for molybdenum species as well, suggesting that this new and unexpected 'carbonyl mechanism' can be quite general for related transformations.

\section{Results and Discussion}

Experimental results on $\mathrm{Mo}(\mathrm{II})$ species. Synthesis and reactivity of $\left[\mathrm{Mo}\left(\eta^{3}-\mathrm{C}_{4} \mathrm{H}_{7}\right)(\mathrm{bipy})(\mathrm{CO})_{2}(\mathrm{~N}-\mathrm{RIm})\right] \mathrm{X} \quad\left(\mathrm{X}=\mathrm{OTf}, \quad \mathrm{BAr}_{4}^{\prime}\right)$ compounds.

The addition of a few drops of acetonitrile to a 1:1 mixture of AgOTf and $\left[\mathrm{MoCl}\left(\eta^{3}-\mathrm{C}_{4} \mathrm{H}_{7}\right)(\right.$ bipy $\left.)(\mathrm{CO})_{2}\right]$ in dichloromethane led immediately to the precipitation of a white solid $(\mathrm{AgCl})$, and the formation of the nitrile compound $\left[\mathrm{Mo}\left(\eta^{3}-\right.\right.$ $\left.\mathrm{C}_{4} \mathrm{H}_{7}\right)\left(\right.$ bipy) $\left.(\mathrm{CO})_{2}(\mathrm{NCMe})\right] \mathrm{OTf}$. From this species the labile MeCN ligand is easily substituted by addition of the equimolar amount of a $N$-alkylimidazole (see Scheme 2), affording the new imidazole compounds $\left[\mathrm{Mo}\left(\eta^{3}-\mathrm{C}_{4} \mathrm{H}_{7}\right)(\right.$ bipy $\left.)(\mathrm{CO})_{2}(N-\operatorname{RIm})\right] \mathrm{OTf}(\mathbf{1}, \mathbf{2})$.

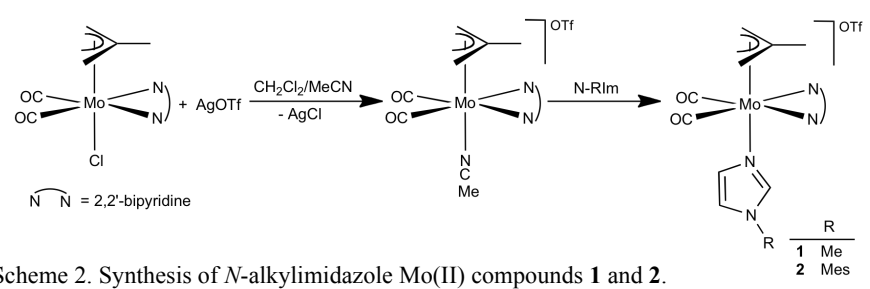

Compounds $\mathbf{1}$ and $\mathbf{2}$ were obtained as the only products of the reactions in good yields ( 1 in $82 \%$, and $\mathbf{2}$ in $85 \%$ ), and were spectroscopically characterized in solution. The IR spectra in the carbonyl region show two intense bands for the cis- $\left\{\mathrm{Mo}(\mathrm{CO})_{2}\right\}$ moiety, at 1951, $1867 \mathrm{~cm}^{-1}$ (1) and 1954, $1869 \mathrm{~cm}^{-1}$ (2), in accordance with their formulation as cationic complexes of the $\left\{\mathrm{Mo}\left(\eta^{3} \text {-allyl)(bipy)(CO)}\right)_{2}\right\}$ fragment. ${ }^{[11]}$ The ${ }^{1} \mathrm{H}$ and ${ }^{13} \mathrm{C}$ NMR spectra of compounds $\mathbf{1}$ and $\mathbf{2}$ show the presence of a molecular mirror plane, and the incorporation of one $N$-alkylimidazole ligand per metal fragment (see Experimental Section).

The addition of the equimolar amount of a strong base to a solution of compound $\mathbf{1}$ in tetrahydrofuran (thf) caused the deprotonation of the $\mathrm{C} 2-\mathrm{H}$ group of the $\mathrm{N}$-methylimidazole ligand, affording the imidazol-2-yl complex 3 (Scheme 3). The IR spectrum of $\mathbf{3}$ is in agreement with the formation of a neutral product ( $\mathrm{v}_{\mathrm{CO}}$ bands at 1931, $1851 \mathrm{~cm}^{-1}$ ) and, accordingly, the ${ }^{1} \mathrm{H}$ NMR shows the presence of only two imidazole $\mathrm{C}-\mathrm{H}$ groups (two broad singlets at 6.71 and $6.38 \mathrm{ppm}$ ). Unfortunately the ${ }^{13} \mathrm{C} \mathrm{NMR}$ spectrum of complex 3 could not be obtained, as it decomposed to unidentified products over the recording time. In a similar way, the deprotonation of the mesitylimidazole compound $\mathbf{2}$ afforded the $C$-bonded imidazolyl complex 4 (Scheme 3), which showed a much higher stability than its methyl analogue 3 . Thus the ${ }^{13} \mathrm{C}$ NMR spectra of 4 could be registered, and it showed a low intensity singlet at 184.5 ppm, characteristic of the Mo-C moiety. The formation of $\mathbf{3}$ and $\mathbf{4}$ involve the change of the heterocycle coordination mode upon deprotonation, from $N$ - to $C$-metal bonded. This type of complexes, featuring a non-substituted nitrogen, $C$-bonded imidazol-2-yl ligand are very scarce, ${ }^{[6 \mathrm{c}-\mathrm{d}, 12]}$ and have been previously proposed for the tautomerization of $N$-alkylimidazole to NHC ligands. ${ }^{[12 c, 8]}$ This behavior resembles that found by our group for the deprotonation of the $\operatorname{Re}(\mathrm{I})$ carbonyl complex with three $N$-methylimidazole ligands, $\left[\operatorname{Re}(\mathrm{CO})_{3}(N-\mathrm{MeIm})_{3}\right] \mathrm{OTf}^{[13]}$ 


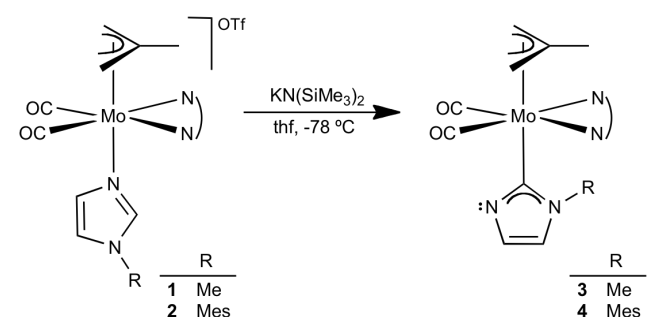

Scheme 3. Deprotonation of compounds $\mathbf{1}$ and $\mathbf{2}$ to afford imidazol-2-yl complexes $\mathbf{3}$ and $\mathbf{4}$, respectively.

Slow diffusion of hexane into a concentrated solution of compound 4 in toluene at $-20{ }^{\circ} \mathrm{C}$ afforded orange crystals, one of which was used for an X-ray structure determination. ${ }^{[14]}$ As shown in Figure 1a, the molybdenum atom displays a pseudooctahedral coordination geometry. The 2,2'-bipyridine chelate is coplanar with the two CO ligands, and the imidazol-2-yl is trans to the $\eta^{3}$-allyl ligand. The Mo- $\mathrm{C}_{\text {imidazolyl }}$ bond distance of $2.236(8) \AA$ is very close to those found for related $\mathrm{Mo}(\mathrm{II}) \mathrm{NHC}$ complexes, ${ }^{[15]}$ including the NH wingtip protonated form of $\mathbf{4}$ (see below).

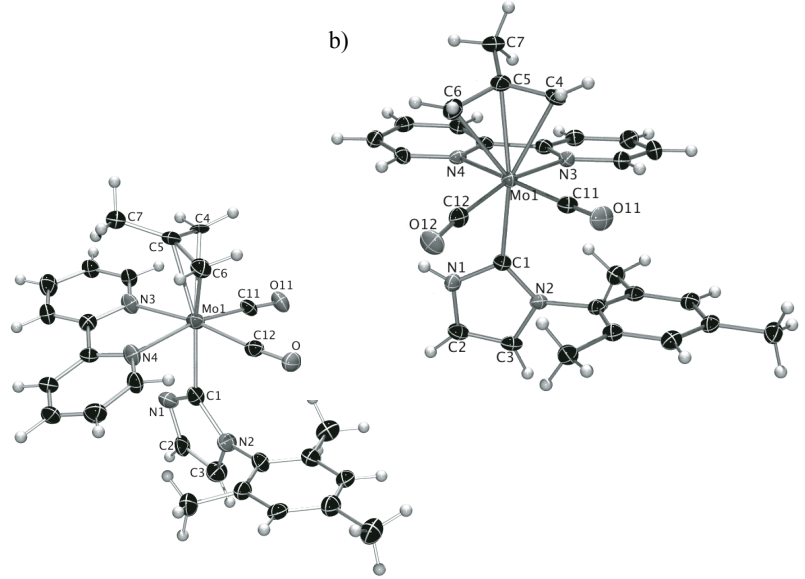

Figure 1. (a) Molecular structure of complex 4. (b) Molecular structure of the cation of compound 6 .

The reaction of the imidazol-2-yl complexes 3 and $\mathbf{4}$ with electrophilic reagents such as trifluoromethanesulfonic acid (HOTf) or methyl or ethyl trifluoromethanesulfonate (MeOTf or EtOTf), led to the formation of NHC complexes upon protonation or alkylation of the non-coordinated nitrogen atom (see Scheme 4).

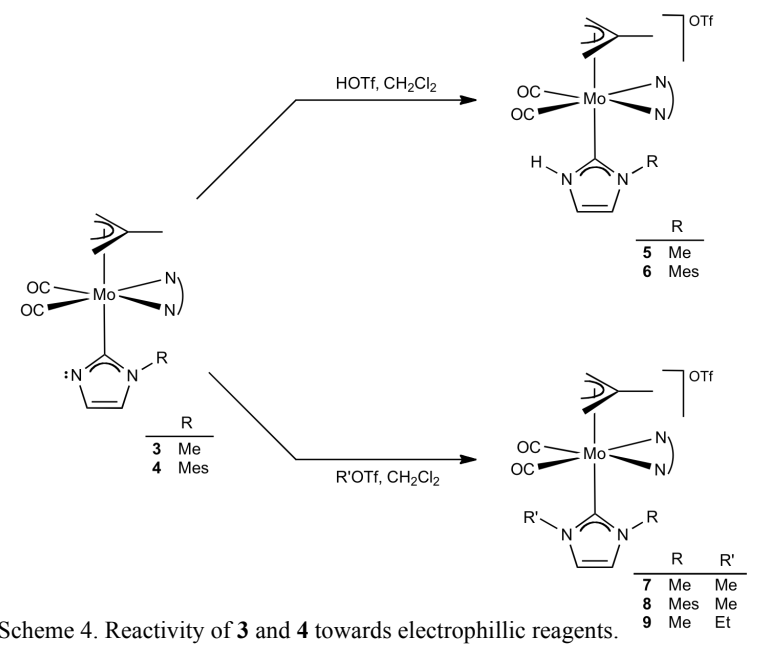

A first indication of the course of these reactions is given by the changes in the carbonyl region in the IR spectra: the $v_{\mathrm{CO}}$ bands of the products (5-9) are much higher than those of the precursors 3 or 4 , reflecting the formation of cationic products from neutral species. For example, in the reaction of complex 4 with HOTf the IR $v_{\mathrm{CO}}$ values change from $1931,1851 \mathrm{~cm}^{-1}$ for 4 to $1949,1872 \mathrm{~cm}^{-1}$ for the NH-NHC compound $\mathbf{6}$. The solid state structure of $\mathbf{6}$ was determined by an X-ray diffraction analysis, and a representation of the NHC molybdenum complex is depicted in Figure $1 b .^{[16]}$

The NH-NHC complex 6 and the imidazol-2-yl complex 4 differ only in the hydrogen on one of the nitrogen atoms of the $\mathrm{N}$ heterocyclic ligand, thus the spectroscopic and structural properties of both ligands are very close. ${ }^{[17]}$ In the ${ }^{13} \mathrm{C}$ NMR spectrum of 6 the carbene carbon is observed at $188.2 \mathrm{ppm}(184.5 \mathrm{ppm}$ for 4$)$, and the Mo- $\mathrm{C}_{\text {carbene }}$ bond distance, of 2.240(3) $\AA$ (2.236(8) $\AA$ for 4) is in good agreement with the reported Mo- $\mathrm{C}_{\text {carbene }}$ distances of related complexes, which are in the range from $2.152(5)$ to $2.35(1) \AA{ }^{[15]}$ Also, for both $N$-heterocyclic ligands (the imidazol-2-yl in $\mathbf{4}$, and $\mathrm{NH}-\mathrm{NHC}$ in 6), their metrical data indicate a high electronic delocalization.

Compounds 3 and 4 can be also methylated on the nonsubstituted nitrogen to afford compounds $\mathbf{7}$ and $\mathbf{8}$ respectively. There is a difference between these compounds: whereas for 7 the resulting NHC ligand is symmetric, bearing a methyl group on each nitrogen atom, for $\mathbf{8}$ the NHC ligand formed is not symmetric as it displays different substituents at the two nitrogens. Due to the symmetry of the NHC ligand, the ${ }^{1} \mathrm{H}$ and ${ }^{13} \mathrm{C}$ NMR spectra of 7 show the signals corresponding to a molecule with a mirror plane, and there is a six hydrogen singlet at $3.45 \mathrm{ppm}$ in the ${ }^{1} \mathrm{H} \mathrm{NMR}$, and at 39.0 in the ${ }^{13} \mathrm{C}$ NMR, for the two $\mathrm{N}-\mathrm{CH}_{3}$ groups. For compound $\mathbf{8}$ the incorporation of one methyl group per metal complex is clearly evidenced by the observation of singlets at $3.97 \mathrm{ppm}$ (that integrates for three hydrogen atoms) and $42.6 \mathrm{ppm}$ in the ${ }^{1} \mathrm{H}$ and ${ }^{13} \mathrm{C}$ NMR spectra respectively.

a)

b)

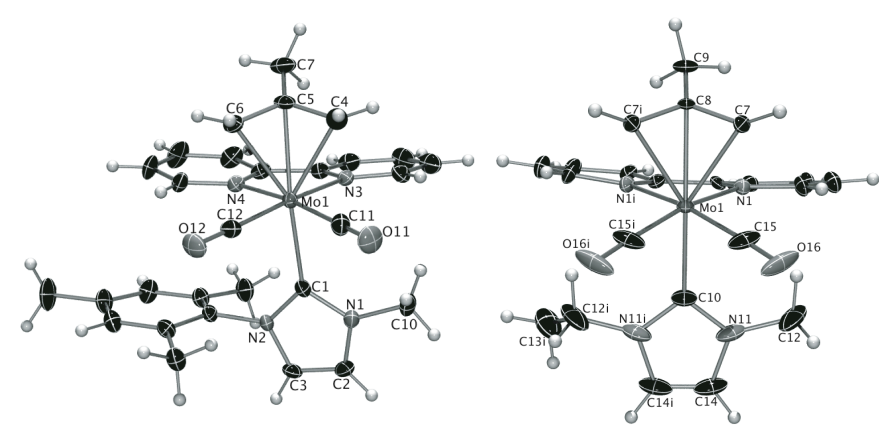

Figure 2. a) Molecular structure of the cation of compound $\mathbf{8 b}$. b) Molecular structure of the cation present in compound $\mathbf{9}$.

Trying to obtain better crystallinity we decided to prepare the cationic imidazole starting compound $\left[\mathrm{Mo}\left(\eta^{3}-\mathrm{C}_{4} \mathrm{H}_{7}\right)(\right.$ bipy $)(\mathrm{CO})_{2}(N-$ MesIm)]BAr' ${ }_{4}$ (2b), analogous to compound 2 but with the $\mathrm{BAr}_{4}$ counteranion instead of OTf. The synthesis of $\mathbf{2} \mathbf{b}$ could be carried out by addition of $\mathrm{NaBAr}_{4}{ }_{4}(\mathrm{Ar}$ ' $=3,5$-bis(trifluoromethyl)phenyl) to the chlorocomplex $\left[\mathrm{MoCl}\left(\eta^{3}-\mathrm{C}_{4} \mathrm{H}_{7}\right)(\right.$ bipy $\left.)(\mathrm{CO})_{2}\right]$ in the presence of a slight excess of the $\mathrm{N}$-MesIm ligand. Note that for this family of 
Mo(II) compounds is not necessary to prepare the triflato species as intermediates (as it was for rhenium compounds), and the addition of the sodium tetraarylborate as halogen abstractor leads directly to substitution of $\mathrm{Cl}^{-}$by the $N$-alkylimidazole ligand. As shown in Scheme 5, the deprotonation/methylation sequence of reactions of compound $\mathbf{2 b}$ allowed the isolation of $\left[\mathrm{Mo}\left(\eta^{3}-\right.\right.$ $\left.\mathrm{C}_{4} \mathrm{H}_{7}\right)$ (bipy) $\left.(\mathrm{CO})_{2}(\mathrm{Me}-\mathrm{NHC}-\mathrm{Mes})\right] \mathrm{BAr}_{4}{ }_{4}(\mathbf{8 b})$.

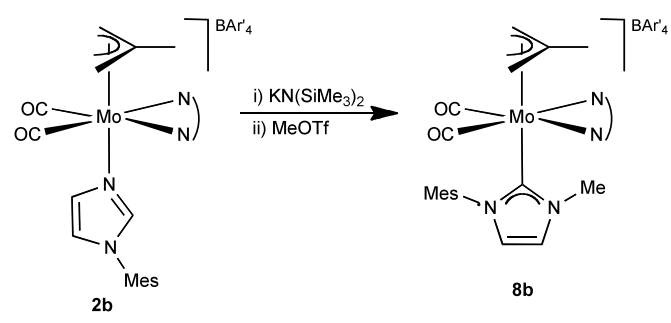

Scheme 5. Synthesis of compound $\mathbf{8 b}$.

Slow diffusion of hexane into a concentrated solution of $\mathbf{8 b}$ in $\mathrm{CH}_{2} \mathrm{Cl}_{2}$ at $-20{ }^{\circ} \mathrm{C}$ afforded crystals, one of which was employed for an X-ray structure determination. ${ }^{[18]}$ As depicted in Figure 2a, the structure was found to be very similar to that of the NH-NHC compound $\mathbf{6}$, but bearing a methyl group instead of a hydrogen atom at one of the $\mathrm{NHC}$ nitrogens. The Mo- $\mathrm{C}_{\text {carbene }}$ bond distance $[2.252(4) \quad \AA]$ is very close to those of other Mo(II)-NHC complexes. $^{[15]}$

As the results of the X-ray structure determination of the methylated compound 7 were of low quality (see Supporting Information), the ethylated complex $\left[\mathrm{Mo}\left(\eta^{3}-\mathrm{C}_{4} \mathrm{H}_{7}\right)(\right.$ bipy $)(\mathrm{CO})_{2}($ EtNHC-Me)]OTf (9) was prepared by reaction of complex 3 with EtOTf (see Experimental Section for further details). Compound 9 was analytically and spectroscopically characterized, and its solid state structure was determined by X-ray difracction (Figure 2b) ${ }^{[19]}$ The structure of the cationic molybdenum complex of compound 9 exhibits the ethyl substituent disordered between the two nitrogen atoms of the heterocyclic ring (labelled N11 and N11i in Figure 2b). It was necessary to include a disordered model with two orientations at $47.8 \%$ and $52.2 \%$ occupancies, showing in Figure $2 \mathrm{~b}$ one of them. For compounds 7 and 9 the respective Mo- $\mathrm{C}_{\text {carbene }}$ distances, of 2.304(5) $\AA$ and 2.276(5) $\AA$, fall in the expected range (see above) for these types of bonds. ${ }^{[15]}$

The reaction of either the methyl or mesityl- imidazol-2-yl complexes 3 and 4 with the equimolar amount of $\left[\mathrm{AuCl}\left(\mathrm{PPh}_{3}\right)\right]$ afforded, in about $30 \mathrm{~min}$. at room temperature, compounds $\mathbf{1 0}$ and 11, respectively (Scheme 6). In these reactions the soft gold (I) fragment displays a higher affinity for the carbenic carbon than for the non-substituted nitrogen, so further than the substitution reaction of the $\mathrm{Cl}^{-}$ligand by the imidazol-2-yl, a translocation of the Mo(II) and $\mathrm{Au}(\mathrm{I})$ metal ions is observed. Hence $\mathbf{1 0}$ and $\mathbf{1 1}$ are heterobimetallic imidazol-2-yl compounds where the heterocyclic ligand is $C$-coordinated to $\mathrm{Au}$ and once again $N$-bonded to the $\mathrm{Mo}(\mathrm{II})$ fragment. Compounds $\mathbf{1 0}$ and $\mathbf{1 1}$ can be considered indeed as $\mathrm{N}$-metalated gold (I) NHC complexes.

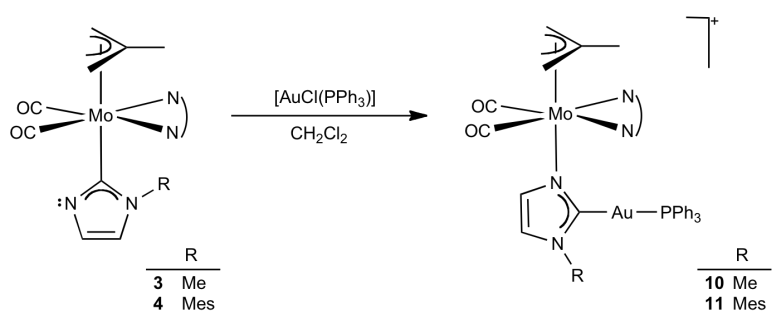

Scheme 6. Synthesis of heterobimetallic imidazol-2-yl compounds $\mathbf{1 0}$ and $\mathbf{1 1 .}$

These kind of transmetalation processes with the $\left\{\mathrm{Au}\left(\mathrm{PPh}_{3}\right)\right\}$ fragment have been previously found for $\operatorname{Re}(\mathrm{I})$ and $\mathrm{Mn}(\mathrm{I})$ imidazol2-yl complexes. ${ }^{[8,13 b]}$ These experimental results are in accordance with the theoretical study carried out by Sini, Eisenstein and Crabtree about the $C$ - or $N$-binding preference of imidazole depending on the nature of the metal fragment. ${ }^{[20]}$

The ${ }^{1} \mathrm{H}$ NMR spectra of compounds $\mathbf{1 0}$ and $\mathbf{1 1}$ showed the incorporation of one $\left\{\mathrm{Au}\left(\mathrm{PPh}_{3}\right)\right\}$ fragment per $\mathrm{Mo}(\mathrm{II})$ atom. In the ${ }^{13} \mathrm{C}$ NMR spectra the most characteristic signal of the new compounds is a low intensity doublet (at 189.9 ppm for $\mathbf{1 0}$, and $192.0 \mathrm{ppm}$ for 11) attributable to the carbenic $\mathrm{C}$ atom, which is coupled with the trans $\mathrm{P}$ atom $\left({ }^{2} J_{\mathrm{C}, \mathrm{P}}=135.6 \mathrm{~Hz}\right.$ for 10, and ${ }^{2} J_{\mathrm{C}, \mathrm{P}}=$ 126.7 $\mathrm{Hz}$ for 11). ${ }^{[21]}$ The ${ }^{31} \mathrm{P}$ NMR spectra show a singlet at 41.1 ppm for both compounds $\mathbf{1 0}$ and $\mathbf{1 1}$ in agreement with the incorporation of the $\left\{\mathrm{Au}\left(\mathrm{PPh}_{3}\right)\right\}$ fragment. Slow diffusion of hexane into a concentrated solution of compound $\mathbf{1 0}$ in $\mathrm{CH}_{2} \mathrm{Cl}_{2}$ afforded red crystals, one of which was employed for an X-ray structure determination. ${ }^{[22]}$ The metal cation found in the solid state structure of $\mathbf{1 0}$ is depicted in Figure 3, where it is shown that, as expected, the molybdenum atom is in a pseudooctahedral geometry. The heterocyclic ligand is $C$-bonded to the $\mathrm{Au}$ atom, therefore the bimetallic complex can be considered a $\mathrm{N}$-metallated cationic NHC gold (I) complex. The coordination geometry of the $\mathrm{Au}$ atom is linear, as expected for a cationic gold (I) complex bearing two ligands, the angle C1-Au1-P1 (172.5(3) ${ }^{\circ}$ ) being slightly distorted. In fact this deviation from the linearity is more pronounced that those found in other $\left[\mathrm{Au}(\mathrm{NHC})\left(\mathrm{PR}_{3}\right)\right]$ complexes (the $\mathrm{P}-\mathrm{Au}-\mathrm{C}_{\text {carbene }}$ angles are between 174.6 and $\left.177.2^{\circ}\right),{ }^{[21 \mathrm{~b}, 23]}$ a fact that can be attributed to the higher steric hindrance of the molybdenum fragment compared to an alkyl or aryl substituent. The Au1-C1 bond distance of 2.0158(10) $\AA$, is similar to other $\mathrm{Au}(\mathrm{I})-\mathrm{C}_{\text {carbene }}$ distances found for similar cationic compounds. ${ }^{[2]}$ The $\mathrm{Au}$ coordination geometry is close to linear with a C1-Au1-P1 angle of 172.5(3) ${ }^{\circ}$. The Mo1-N1 bond distance, of 2.219(8) $\AA$, is similar to other molybdenum (II) imidazole distances previously reported. ${ }^{[11 \mathrm{a}, 25]}$

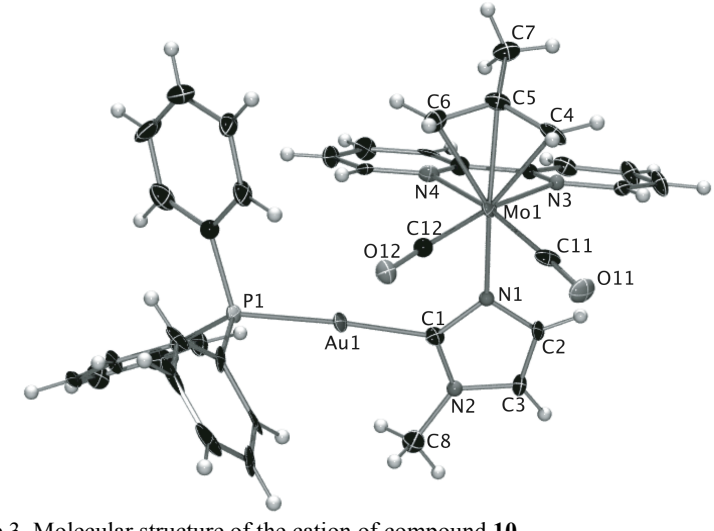

Figure 3. Molecular structure of the cation of compound $\mathbf{1 0}$. 
DFT calculations for the deprotonation of $\left[\mathrm{M}(\mathrm{bipy})(\mathrm{CO})_{3}(\mathrm{~N}\right.$ $\operatorname{RIm})]^{+}(M=M n, \quad \operatorname{Re})$ and $\left[\mathrm{Mo}\left(\eta^{3}-\mathrm{C}_{4} \mathrm{H}_{7}\right)(\mathrm{bipy})(\mathrm{CO})_{2}(\mathrm{~N}-\right.$ MesIm) $]^{+}$complexes.

As we have mentioned in the preceding section the deprotonation of $\left[\mathrm{Mo}\left(\eta^{3}-\mathrm{C}_{4} \mathrm{H}_{7}\right)(\right.$ bipy $)(\mathrm{CO})_{2}(N$-RIm) $] \mathrm{OTf}(\mathrm{R}=\mathrm{Me}$, Mes) compounds leads to the formation of imidazol-2-yl species ( $\mathbf{3}$ and $\mathbf{4}$ in Scheme 3 ), resembling the behavior previously found for the complex $\left[\mathrm{Mn}(\mathrm{CO})_{3} \text { (bipy) }(\mathrm{N}-\mathrm{PhIm})\right]^{+} \cdot{ }^{[8]}$ In contrast, the deprotonation of $\left[\operatorname{Re}(\mathrm{CO})_{3}(\text { bipy })(N-\mathrm{RIm})\right]^{+}(\mathrm{R}=\mathrm{Me}$, Mes $)$ complexes affords the formation of $\mathrm{C}-\mathrm{C}$ coupling products. ${ }^{[9]}$ To understand the different nature of the deprotonation products, depending on the metal fragment, we investigated the mechanism of the deprotonation of $\left[\mathrm{Mn}(\text { bipy })(\mathrm{CO})_{3}(\mathrm{~N}-\mathrm{PhIm})\right]^{+}, \quad\left[\operatorname{Re}(\text { bipy })(\mathrm{CO})_{3}(N-\mathrm{Mes} I m)\right]^{+}, \quad$ and $\left[\mathrm{Mo}\left(\eta^{3}-\mathrm{C}_{4} \mathrm{H}_{7}\right)(\text { bipy })(\mathrm{CO})_{2}(N \text {-MesIm })\right]^{+}$complexes at the B3LYP/6$31 \mathrm{G}(\mathrm{d})$ (LANL2DZ for Mn, Re, and Mo) theory level. On the basis of previous experimental and theoretical studies on related systems, ${ }^{[8,13 b, 26]}$ the corresponding deprotonated counterparts of the three above-mentioned complexes, I-M (M=Mn, Re, Mo), have been taken as the starting critical structures. As shown in Scheme 6, I-M can evolve through three different routes. The route leading to a C-C coupling product, pathway A in Scheme 7, resembles that obtained as the favored route for the deprotonation of $\left[\operatorname{Re}(\mathrm{CO})_{3}(\mathrm{~N}\right.$ $\left.\left.\mathrm{R}^{1} \mathrm{Im}\right)_{2}\left(N-\mathrm{R}^{2} \mathrm{Im}\right)\right]^{+} \quad\left(\mathrm{R}^{1}=\mathrm{R}^{2}=\mathrm{Ph} ; \mathrm{R}^{1}=\mathrm{Me}, \mathrm{R}^{2}=\mathrm{Mes}\right)$ complexes. ${ }^{[13 \mathrm{~b}]}$ The two remaining reaction mechanisms, pathways $\mathrm{B} 1$ and $\mathrm{B} 2$ in Scheme 6, afford the same product, an imidazol-2-yl complex. The former is analogous to that proposed to explain the deprotonation of $\left[\operatorname{Re}(\mathrm{CO})_{3}(N \text {-MeIm })_{3}\right]^{+},{ }^{[13 \mathrm{~b}]}$ while the latter resembles the recently found mechanism for the deprotonation of $\left[\mathrm{Mn}(\right.$ bipy $)(\mathrm{CO})_{3}(\mathrm{~N}-$ $\mathrm{PhIm})]^{+} \cdot{ }^{[10]}$ Figures S1-S3 in the Supporting Information collect the optimized geometries of all the species involved in the reaction pathways investigated and Tables S1 and S2 their energy data. Unless otherwise stated we will give in the text the Gibbs energy in solution of all the located species relative to that of the corresponding starting complex I-M. It is interesting to note that for Mo the presence of the allyl ligand instead of the axial CO does not modify significantly the relative orientation of the remaining ligands around the metal center, and the located Mo-containing intermediates and transition states are similar to those found for $\mathrm{Mn}$ and $\mathrm{Re}$. In pathway $\mathrm{A}$, the deprotonated $\mathrm{C}$ atom of the imidazole ring attacks one of the bipy ortho $\mathrm{C}$ atoms to afford the product $\mathbf{P a}$ $\mathbf{M n} / \mathbf{P a}-\mathbf{R e} / \mathbf{P a}-\mathbf{M o}, 5.8 / 12.6 / 8.1 \mathrm{kcal} \mathrm{mol}^{-1}$ more stable than I-Mn/I$\mathbf{R e} / \mathbf{I}-\mathbf{M o}$. The formation of these C-C coupling products implies a Gibbs energy barrier of 9.0/4.8/8.3 $\mathrm{kcal} \mathrm{mol}^{-1}$ via the transition state (TS) TSa-Mn/TSa-Re/TSa-Mo (Scheme 7). The distance between the deprotonated imidazole and bipy ortho $\mathrm{C}$ atoms vary from $2.207 / 2.320 / 2.287 \AA$ in TSa-Mn/TSa-Re/TSa-Mo to $1.543 / 1.540 / 1.540 \AA$ in Pa-Mn/Pa-Re/Pa-Mo, a fact that clearly indicates the formation of a new $\mathrm{C}-\mathrm{C}$ bond. The $\mathrm{C}-\mathrm{C}$ coupling products Pa-M could evolve to ring-opening species, in a similar way than that found for $\left[\operatorname{Re}(\mathrm{CO})_{3}\left(N-\mathrm{R}^{1} \mathrm{Im}\right)_{2}\left(N-\mathrm{R}^{2} \mathrm{Im}\right)\right]^{+}\left(\mathrm{R}^{1}=\mathrm{R}^{2}=\mathrm{Ph}\right.$; $\left.\mathrm{R}^{1}=\mathrm{Me}, \mathrm{R}^{2}=\mathrm{Mes}\right)$ complexes. ${ }^{[13 \mathrm{~b}]}$ However, the relative stability of $\mathbf{P a}-\mathbf{M n} / \mathbf{P a}-\mathbf{R e} / \mathbf{P a}-\mathbf{M o}$ along with the high Gibbs energy barrier required for the formation of the ring-opening products (see TSPa$\mathbf{M}$, in Table S2 in the Supporting Information) clearly prevents their formation. Pathway B1 proceeds through a TS in which the metal centre simultaneously interacts with the $\mathrm{N}$ initially coordinated to the metal and with the deprotonated $\mathrm{C}$ atom of the imidazole ligand, to afford an imidazol-yl product. It is noteworthy that, after an extensive exploration of the potential energy surface, such TS was only found for rhenium, TSb1-Re, with an electronic energy barrier of $15.3 \mathrm{kcal} \mathrm{mol}^{-1}$. Pathway B2 comprises two steps. The first step

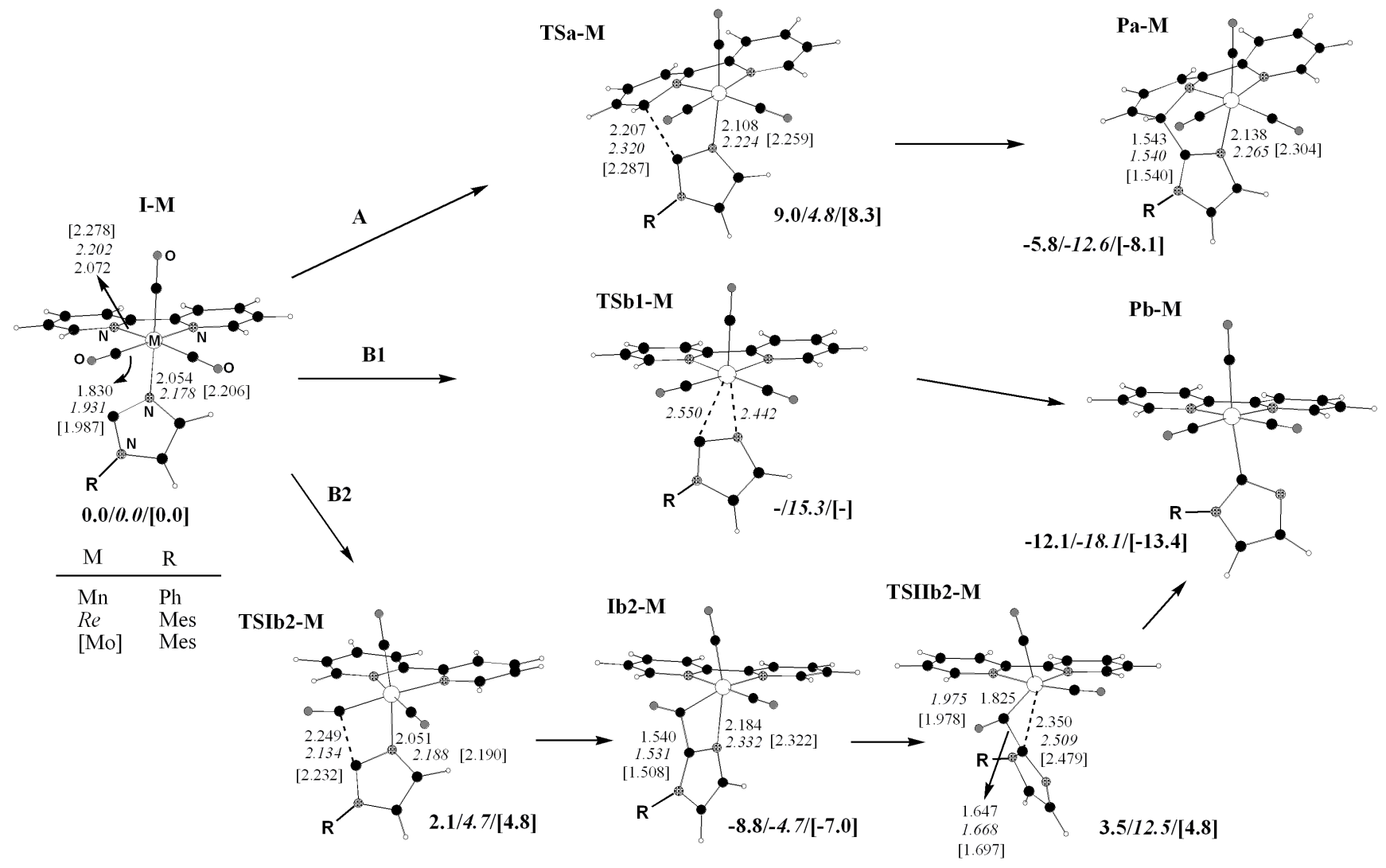

Scheme 7. Schematic view of the reaction mechanisms found for the deprotonation reaction of $\left[\mathrm{Mn}(\mathrm{bipy})(\mathrm{CO})_{3}(\mathrm{~N}-\mathrm{PhIm})\right]^{+}$, $\left[\mathrm{Re}(\mathrm{bipy})(\mathrm{CO})_{3}(\mathrm{~N}-\mathrm{MesIm})\right]^{+}$, and $\left[\mathrm{Mo}\left(\eta^{3}-\right.\right.$ $\left.\mathrm{C}_{4} \mathrm{H}_{7}\right)\left(\text { bipy) }(\mathrm{CO})_{2}(\mathrm{~N}-\mathrm{MesIm})\right]^{+}$at the B3LYP/6-31G(d) (LANL2DZ for Mn, Re, and Mo) level of theory. Main bond distances (in $\AA$ ) and relative Gibbs energies in solution (in

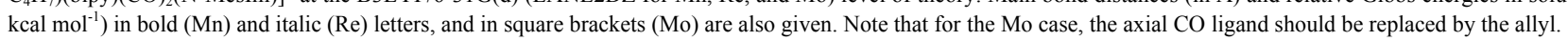


corresponds to the attack of the deprotonated imidazole carbon to one equatorial carbonyl $\mathrm{C}$ atom through TSIb2-Mn/TSIb2Re/TSIb2-Mo, $\left(2.1 / 4.7 / 4.8 \mathrm{kcal} \mathrm{mol}^{-1}\right)$ to afford the intermediate Ib2-Mn/Ib2-Re/Ib2-Mo, $8.8 / 4.7 / 7.0 \mathrm{kcal} \mathrm{mol}^{-1}$ more stable than the starting complexes I-Mn/I-Re/I-Mo. These intermediate species feature a new $\mathrm{C}-\mathrm{C}$ bond [the $\mathrm{C}_{\text {deprotonated }} \mathrm{C}_{\text {carbonyl }}$ bond distances are $1.540,1.531$ and $1.508 \AA$ for $\mathrm{Mn}, \mathrm{Re}$ and Mo fragments, respectively], and a considerable lengthening of the M-N(imidazole) bond [from 2.054/2.178/2.206 $\AA$ in I-Mn/I-Re/I-Mo to 2.184/2.332/2.322 $\AA$ in Ib2-Mn/Ib2-Re/Ib2-Mo]. The second step evolves through the TS TSIIb2-Mn/TSIIb2-Re/TSIIb2-Mo to finally reach the corresponding imidazol-2-yl product $\mathbf{P b}-\mathbf{M n} / \mathbf{P b}$ $\mathbf{R e} / \mathbf{P b}-\mathbf{M o}, 12.1 / 18.1 / 13.4 \mathrm{kcal} \mathrm{mol}^{-1}$ under the reactant complex. This step shows a significant rearrangement of the molecular system: cleavage of the metal-N(imidazole) bond, rotation of the $\mathrm{N}$ $\mathrm{RIm}$ ligand around the $\mathrm{C}$ (deprotonated)-C(carbonyl) bond, formation of the new metal-C(deprotonated) bond, and cleavage of the $\mathrm{C}$ (deprotonated)-C(carbonyl) bond. As a consequence, TSIIb2Mn/TSIIb2-Re/TSIIb2-Mo is the rate-determining TS of pathway B2 with an energy barrier of 12.3/17.2/11.8 $\mathrm{kcal} \mathrm{mol}^{-1}$.

\section{Discussion of the theoretical results}

For pathway A, a natural bond order analysis of TSaMn/TSa-Mo/TSa-Re reveals the existence of a strong interaction between the $\sigma$ bonding $\mathrm{C}($ deprotonated)-C(ortho) and the $\sigma$ antibonding $\mathrm{C}$ (ortho)-N(bipy) with a second order perturbation energy, $\mathrm{E}(2)$, of about $16 / 20 / 53 \mathrm{kcal} \mathrm{mol}^{-1}$, thus indicating an electron delocalization towards the attacked $\mathrm{C}($ ortho $)$-N(bipy) bond of the bipy ligand. In agreement with this, the natural electron charge at that $\mathrm{N}$ atom increases from $-0.40 /-0.45 /-0.45$ e to $-0.48 /-$ $0.52 /-0.53$ e when going from I-Mn/I-Mo/I-Re to TSa-Mn/TSa-
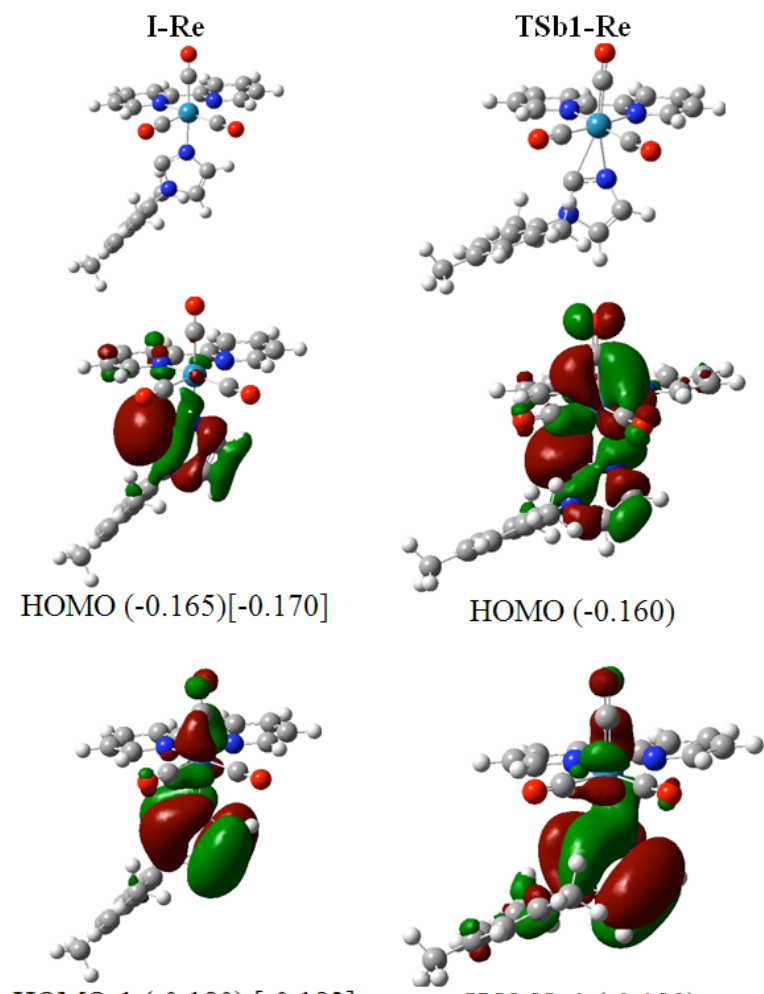

HOMO-1 (-0.180) [-0.182]

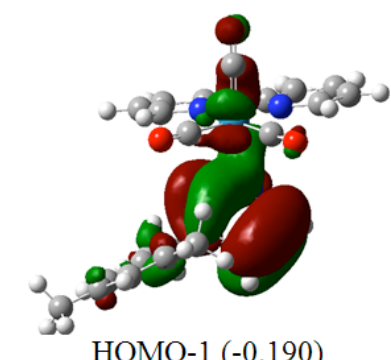

HOMO-1 (-0.190)

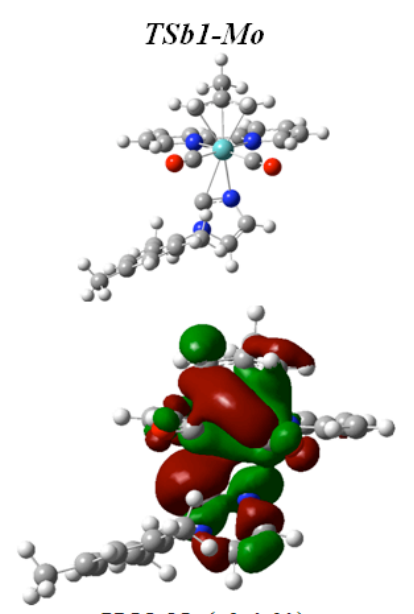

$\operatorname{HOMO}(-0.161)$

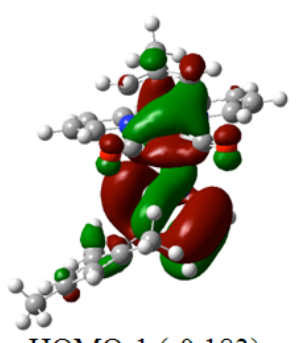

HOMO-1 (-0.183)

Figure 4. Most significant MOs of the B3LYP/6-31G(d) (LANL2DZ for Mn, Re, and Mo) optimized structures for IRe,TSb1-Re, and TSb1-Mo. Orbital energies are shown in $\mathrm{eV}$ in parenthesis. As a reference, orbital energies in square brackets are also displayed for I-Mo.

Mo/TSa-Re, respectively. The stabilizing interaction mentioned above will partly compensate the destabilization caused by the loss of aromaticity of the bipy ligand. Based on the $\mathrm{E}(2)$ values, that compensation is more accentuated for Re than for Mn and Mo, thus explaining the obtained relative stability order in Gibbs energy in solution TSa-Re $\left(4.8 \mathrm{kcal} \mathrm{mol}^{-1}\right)>$ TSa-Mo $\left(8.3 \mathrm{kcal} \mathrm{mol}^{-1}\right)>\mathbf{T S a}-$ Mn $\left(9.0 \mathrm{kcal} \mathrm{mol}^{-1}\right)$.

The occurrence of TSb1-Re over the lack of such a critical structure for Mn and Mo can be rationalized through the molecular orbitals (MO) involving the metal and its ligands. As seen in Figure 4 the passage I-Re $\rightarrow$ TSb1-Re implies a destabilization of the OMO due to a significant increase of the participation of the bonding interaction between Re and the CO ligand in axial position. The reverse trend was found for HOMO-1 owing to a stabilizing interaction between the metal center and the imidazole moiety. To obtain the hypothetical analogous species TSb1-Mn and TSb1-Mo for Mn and Mo respectively, the metal center and the corresponding ligands have been replaced at TSb1-Re. For both cases, the description of the most significant MO is similar to that found for Re. However, it is interesting to note that the HOMO destabilization is almost double than that for Re when going from I-M to TSb1-M. In contrast, HOMO-1 for Mn and Mo stabilizes notably less than that for Re. Similar trends were also obtained for other significant occupied MOs. In accordance with this, TSb1-Mn and TSb1-Mo are 30.1 and $28.1 \mathrm{kcal} \cdot \mathrm{mol}^{-1}$ less stable in electronic energy than I-Mn and I-Mo, respectively. Given the similarity in energy of the MOs of the fragments involving TSb1-M (that is, the imidazole and the remaining metal species), a less effective overlap of the MOs involving the imidazole moiety and the remaining complex seems to be the main responsible for the nonexistence of TSb1-M for Mn and Mo.

Regarding pathway $\mathrm{B} 2$, the relative stability of TSIb2-M and TSIIb2-M $(\mathbf{M}=\mathrm{Mn}, \mathrm{Mo}$, and $\mathrm{Re})$ can be interpreted in terms of the lability of the metalcoordinated ligands. First, based on the computed atomic radii from theoretical models for $\mathrm{C}(0.67 \AA), \mathrm{N}(0.56 \AA), \mathrm{Mn}$ $(1.61 \AA)$, Mo $(1.90 \AA)$, and $\operatorname{Re}(1.88 \AA),{ }^{[27]}$ our theoretical results indicate that the Mn(CO) $)_{\text {equatorial }}$ bond distance at I-Mn compared to that obtained from the sum of the atomic radii, $\mathrm{r}(\mathrm{C})+\mathrm{r}(\mathrm{Mn})$, is less shortened (19.7\%) than those found for Mo (22.7\%) and $\operatorname{Re}(24.3 \%)$. In addition to this, the attacked carbonyl $\mathrm{C}$ atom at I-Mn features a positive natural charge $(0.68 \mathrm{e})$ higher than those at I-Mo (0.59 e) and I$\operatorname{Re}(0.60$ e). Therefore, the nucleophillic attack to the equatorial carbonyl ligand is more favored at I-Mn than at I-Mo and IRe, a fact that is in accordance with that TSIb2-Mn is 2.6 and $2.7 \mathrm{kcal} \mathrm{mol}^{-1}$ more stable than TSIb2-Re and TSIb2-Mo, respectively. Although the second step implies a more complex molecular rearrangement than the first one, focusing our attention on the cleavage of the metal- 
$\mathrm{N}$ (imidazole) bond, the Mn-N(imidazole) bond distance at I-Mn compared to that obtained from the sum of the atomic radii, $\mathrm{r}(\mathrm{Mn})+\mathrm{r}\left(\mathrm{N}_{\mathrm{Im}}\right)$ is less shortened $(5.3 \%)$ than those for Mo (10.3\%) and $\operatorname{Re}(10.7 \%)$. This fact along with that mentioned above for the metal-(CO) equatorial can explain the relative stability order TSIIb2Mn $>$ TSIIb2-Mo $>$ TSIIb2-Re found.

\section{Comparison of theoretical and experimental results}

After rationalizing the Gibbs energy barriers in solution of the different reaction mechanisms found, let us now explain the products found experimentally on the basis of our theoretical results. Figure 5 shows a schematic view of the Gibbs energy profiles in solution of the different pathways found for the evolution of I-M ( $\mathrm{M}=\mathrm{Mn}, \mathrm{Re}$ and $\mathrm{Mo}$ ) complexes we focused on in this study. better kinetic accessibility of Ib2-Mn/Ib2-Mo in conjunction with the fact that its evolution to $\mathbf{P b}-\mathbf{M n} / \mathbf{P b}-\mathbf{M o}$ shows a Gibbs energy barrier in solution $\left.\left(12.3 / 11.8 \mathrm{kcal} \mathrm{mol}^{-1}\right)\right)$ clearly lower than that for the reversion to $\mathbf{P a}-\mathbf{M n} / \mathbf{P a}-\mathbf{M o}\left(17.8 / 15.3 \mathrm{kcal} \mathrm{mol}^{-1}\right)$ via I-Mn/I$\mathbf{M o}$, and that the $\mathbf{P b}-\mathbf{M n} / \mathbf{P b}-\mathbf{M o}$ products are considerably stable $\left(12.1 / 13.4 \mathrm{kcal} \mathrm{mol}^{-1}\right)$ make B2 the most favorable pathway, affording the formation of imidazol-2-yl products instead of the C-C coupling species, as it is encountered experimentally.

\section{Conclusion}

Deprotonation of $\left[\mathrm{Mo}\left(\eta^{3}-\mathrm{C}_{4} \mathrm{H}_{7}\right)(\right.$ bipy $\left.)(\mathrm{CO})_{2}(\mathrm{~N}-\mathrm{RIm})\right] \mathrm{OTf}(\mathbf{1}$ and 2) compounds affords the neutral imidazol-2-yl complexes 3 and 4 . Imidazol-2-yl complexes have been proposed as intermediates in the transformation from a N-alkylmidazole to a NHC ligand. Complexes 3 and $\mathbf{4}$ could be isolated, and for the mesityl derivative 4 the solid state structure was determined by $\mathrm{X}$-ray diffraction. The reaction of these imidazolyl complexes with electrophilic reagents (HOTf, MeOTf or EtOTf) leads to protonation or alkylation of the non-substituted nitrogen, affording molybdenum NHC compounds. Interestingly, these transformations parallel those previously reported for manganese bipy tricarbonyl complexes, in spite of the difference in metal, oxidation state, electron configuration and geometry, but differ from those for similar rhenium compounds. The reactions of 3 or 4 with $\left[\mathrm{AuCl}\left(\mathrm{PPh}_{3}\right)\right]$ afford bimetallic compounds in which the heterocyclic ligand is $C$-coordinated to $\mathrm{Au}$ and, as in the starting imidazole complexes, $N$-bonded to the $\mathrm{Mo}(\mathrm{II})$ fragment. These products can be regarded as N-metallated NHC gold (I) compounds.

The deprotonation of $\left[\mathrm{Mn}(\text { bipy })(\mathrm{CO})_{3}(\mathrm{~N}-\mathrm{PhIm})\right]^{+}$,

$\left[\operatorname{Re}(\text { bipy })(\mathrm{CO})_{3}(\mathrm{~N}-\mathrm{Mes} I m)\right]^{+}, \quad$ and

5. Gibbs energy profiles in solution of the reaction mechanisms found for the deprotonation react $\left[\mathrm{Mn}(\text { bipy })(\mathrm{CO})_{3}(\mathrm{~N}-\mathrm{PhIm})\right]^{+}$, $\left[\mathrm{Re}(\text { bipy })(\mathrm{CO})_{3}(\mathrm{~N}-\mathrm{MesIm})\right]^{+}$, and $\left[\mathrm{Mo}\left(\eta^{3}-\mathrm{C}_{4} \mathrm{H}_{7}\right)(\text { bipy })(\mathrm{CO})_{2}(\mathrm{~N}-\mathrm{MesIm})\right]^{+}$at the B3LYP/6$31 \mathrm{G}(\mathrm{d})$ (LANL2DZ for Mn, Re, and Mo) level of theory. Gibbs energies are also given in $\mathrm{kcal} \mathrm{mol}^{-1}$ in parentheses.
For the rhenium complex, pathway A features a Gibbs energy barrier in solution $\left(4.8 \mathrm{kcal} \mathrm{mol}^{-1}\right)$ notably lower than the required for pathways B1 $\left(15.3 \mathrm{kcal} \mathrm{mol}^{-1}\right)$ and B2 $\left(17.2 \mathrm{kcal} \mathrm{mol}^{-1}\right)$. This fact is in accordance the experimental formation of the $\mathrm{C}-\mathrm{C}$ coupling product, which has been fully characterized including the determination of the solid-state structure by X-ray diffraction. For $\mathrm{Mn}$ and Mo, pathway A is energetically also more favored than pathway B2, but the rate-determining Gibbs energy barriers for pathway $\mathrm{B} 2,12.3 \mathrm{kcal} \mathrm{mol}^{-1}(\mathrm{Mn})$ and $11.8 \mathrm{kcal} \mathrm{mol}^{-1}(\mathrm{Mo})$, are clearly lower than in the Re case $\left(17.2 \mathrm{kcal} \mathrm{mol}^{-1}\right)$. Even more, the difference in the rate-limiting Gibbs energy barriers in solution between pathways A and B2 for Mn and Mo are small (3.3 and 3.5

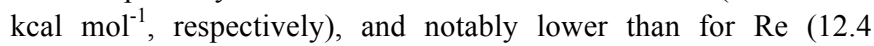
$\mathrm{kcal} / \mathrm{mol}$ ). For $\mathrm{Mn}$ and Mo therefore the route A is not so favored over route B2 as for Re. In addition to this, the formation of Ib2Mn/Ib2-Mo (-8.8/-7.0 $\left.\mathrm{kcal} \mathrm{mol}^{-1}\right)$ implies a Gibbs energy barrier of only $2.1 / 4.8 \mathrm{kcal} \mathrm{mol}^{-1}$, which is clearly lower than the required one for obtaining Pa-Mn/Pa-Mo products $\left(9.0 / 8.3 \mathrm{kcal} \mathrm{mol}^{-1}\right)$. The
$\left[\mathrm{Mo}\left(\eta^{3}-\mathrm{C}_{4} \mathrm{H}_{7}\right)(\text { bipy })(\mathrm{CO})_{2}(\mathrm{~N}-\mathrm{Mes} \mathrm{Im})\right]^{+}$complexes was investigated at the B3LYP/6-31G(d) (LANL2DZ for Mn, Re, and Mo) level of theory both in gas phase and in solution. Three different reaction mechanisms were found. One of them leads to a C-C coupling product, while the remaining pathways evolving through either a three-centre interaction between the metal and the imidazole $\mathrm{C}_{\text {deprotonated }}-\mathrm{N}_{\text {non-substitued }}$ bond or an interaction between the imidazole $\mathrm{C}_{\text {deprotonated }}$ atom and one of the equatorial $\mathrm{C}_{\text {carbonyl }}$ atom give rise to the formation of imidazol-2-yl products. For the Re complex, the reaction pathway leading to the $\mathrm{C}-\mathrm{C}$ coupling product is notably more favored than those that lead to the formation of the imidazolyl product, in agreement with the experimental results. In contrast, the smaller stabilizing interaction between the deprotonated imidazole and ortho bipy C atoms at TSa-Mn and TSa-Mo, along with the higher lability of the ligands bonded to $\mathrm{Mn}$ and Mo fragments, significantly favor the carbonyl mechanism over the C-C coupling one, making the former kinetically more accessible. In agreement with these theoretical results, imidazol-2-yl products are experimentally obtained for the $\mathrm{Mn}$ and Mo complexes. 


\section{Experimental Section}

General: All manipulations were carried out under a nitrogen atmosphere using Schlenk techniques. Solvents were distilled from $\mathrm{Na}$ (toluene and hexanes), $\mathrm{Na}$ /benzophenone (thf) and $\mathrm{CaH}_{2} \quad\left(\mathrm{CH}_{2} \mathrm{Cl}_{2}\right)$. Compounds $\left[\mathrm{MoCl}\left(\eta^{3}-\right.\right.$ $\left.\mathrm{C}_{4} \mathrm{H}_{7}\right)($ bipy $\left.)(\mathrm{CO})_{2}\right],{ }^{[28]}\left[\mathrm{AuCl}\left(\mathrm{PPh}_{3}\right)\right],{ }^{[29]} \mathrm{N}-\mathrm{MesIm}{ }^{[30]}$ and $\mathrm{NaBAr}^{\left[{ }_{4}{ }^{[31]} \text { were prepared as }\right.}$ previously reported. Deuterated dichloromethane (Cambridge Isotope Laboratories, Inc.) was stored under nitrogen in a Young tube and used without further purification. ${ }^{1} \mathrm{H}$ NMR and ${ }^{13} \mathrm{C}$ NMR spectra were recorded on a Bruker Advance 300, DPX-300 or Avance 400 spectrometer. NMR spectra are referred to the internal residual solvent peak for ${ }^{1} \mathrm{H}$ and ${ }^{13} \mathrm{C}\left\{{ }^{1} \mathrm{H}\right\}$ NMR. IR solution spectra were obtained in a Perkin-Elmer FT $1720-\mathrm{X}$ spectrometer using $0.2 \mathrm{~mm}$. $\mathrm{CaF}_{2}$ cells. NMR samples were prepared under nitrogen using Kontes manifolds purchased from Aldrich. Full experimental details of all compounds are given in the Supporting Information, whereas herein only the more representative compounds are included.

Crystal Structure Determination. General Description: For Compounds 4, 8b, 9 and 10. Crystal data were collected on a Bruker APPEX II diffractometer using graphite-monochromated Mo K $\alpha$ radiation $(\lambda=0.71073 \AA)$ from a fine-focus sealed tube source at $100 \mathrm{~K}$. Computing data and reduction were made with the APPEX II software. $^{[32]}$ In all cases empirical absorption corrections were applied using SADABS ${ }^{[33]}$ For compound 6: data collection was performed at $100(2) \mathrm{K}$ on an Oxford Diffraction Xcalibur Nova single crystal diffractometer, using $\mathrm{Cu}-\mathrm{K} \alpha$ radiation $(\lambda=1.5418 \AA)$. Images were collected at a $65 \mathrm{~mm}$ fixed crystal-detector distance, using the oscillation method, with $1^{\circ}$ oscillation and variable exposure time per image (4-16 s). Data collection strategy was calculated with the program CrysAlis ${ }^{\text {Pro }} \mathrm{CCD} .^{\left[{ }^{[4]}\right.}$ Data reduction and cell refinement was performed with the program CrysAlis ${ }^{\text {Pro }}$ RED $^{\left[{ }^{[34]}\right.} \mathrm{An}$ empirical absorption correction was applied using the SCALE3 ABSPACK. ${ }^{[34]}$ In all cases the structures were solved using SIR92 $2^{[35]}$ or SIR97 ${ }^{[36]}$ (compound 6) and finally refined by full-matrix, least-squares based on $F^{2}$ by SHELXL. ${ }^{[37]}$ Molecular graphics were made with ORTEP $3{ }^{[38]}$ CCDC-809055 (4), CCDC-809056 (10), CCDC-809057 (9) , CCDC-809058 (8b) and CCDC-809059 (6) contain supplementary crystallographic data for this paper. These data can be obtained free of charge via www.ccdc.cam.ac.uk/conts/retrieving.html (or from the Cambridge Crystallographic Centre, 12 Union Road, Cambridge CB2 1EZ, UK; Fax: (+44) 1223-336033; or deposit@ccdc.cam.ac.uk).

Computational Details. Quantum chemical computations were carried out with the Gaussian 03 series of programs. ${ }^{[39]}$ Full geometry optimizations of stable species and TS were performed in the gas phase by employing the hybrid density functional B3LYP ${ }^{[40]}$ with the $6-31 \mathrm{G}(\mathrm{d})$ basis set for nonmetal atoms ${ }^{[41]}$ together with the LANL2DZ for Mn, Mo, and $\mathrm{Re}^{[42]}$ and by using the standard Schlegel's algorithm. ${ }^{[43]}$ The B3LYP functional combines the Becke's three-parameter nonlocal hybrid exchange potential with the nonlocal correlation functional of Lee, Yang, and Parr. The nature of the stationary points was verified by analytical computations of harmonic vibrational frequencies. Intrinsic reaction coordinate (IRC) calculations with the Gonzalez and Schlegel method were carried out to check the two minimum energy structures connecting each TS ${ }^{[44]} \Delta \mathrm{H}, \Delta \mathrm{S}$, and $\Delta \mathrm{G}$ were also calculated within the ideal gas, rigid rotor, and harmonic oscillator approximations at a pressure of $1 \mathrm{~atm}$ and a temperature of $298.15 \mathrm{~K}$ for the Mn case and of $195.15 \mathrm{~K}$ for the Mo and Re ones. ${ }^{[4]}$ Solvent effects were taken into account with the Conductor Polarizable Continuum Model (C-PCM) together with the united atom Kohn-Sham (UAKS) parameterization (see the Supporting Information for the discussion about the passage from electronic energies to Gibbs energies in solution via Gibbs energies in the gas phase)..A relative permittivity of 7.58 was assumed in the calculations to simulate tetrahydrofuran as the solvent experimentally used for all the cases. ${ }^{[46]}$ For interpretation purposes, a natural bon orbital (NBO) analysis was also performed. ${ }^{[47]}$ Moreover, single-point energy calculations on the B3LYP/6-31G(d) (LANL2DZ for Mn, Mo, and Re) optimized geometries were carried out both in the same B3LYP functional by using the basis sets $6-31++\mathrm{G}(\mathrm{d}, \mathrm{p})$ and $6-311++\mathrm{G}(\mathrm{d}, \mathrm{p})^{[41]}$ (LANL2DZ for metals) and in the same 6-31G (d) (LANL2DZ for metals) basis with the DFT functionals PBE, ${ }^{[4]}$ BB95, ${ }^{[48]}$ TPSS, ${ }^{[49}$ BH\&HLYP ${ }^{[49 a, 51]}$ TPSSh $^{[52]}$ BMK ${ }^{[53]}$ and M06. ${ }^{[54]}$ Gaussian 09 series of programs ${ }^{[55]}$ instead Gaussian 03 was used to perform the BMK and M06 calculations. As it can be deduced from Tables S3 and S4 and the corresponding discussion in the Supporting Information, the energy discrepancies do not vary the main trends obtained at the B3LYP/6-31G(d) (LANL2DZ for metal atoms) theory level. Therefore, all of this confirms the validity of the computational level chosen to investigate the geometry and energy of the species involved in the deprotonation processes proposed in this work.

Synthesis of $\left[\mathrm{Mo}\left(\boldsymbol{\eta}^{3}-\mathrm{C}_{4} \mathrm{H}_{7}\right)(\right.$ bipy $)(\mathrm{CO})_{2}(\boldsymbol{N}$-MeIm) $]$ OTf (1). AgOTf (70 mg, 0.27 $\mathrm{mmol})$ was added to a solution of $\left[\mathrm{MoCl}\left(\eta^{3}-\mathrm{C}_{4} \mathrm{H}_{7}\right)(\right.$ bipy $\left.)(\mathrm{CO})_{2}\right](100 \mathrm{mg}, 0.25 \mathrm{mmol})$ in $\mathrm{CH}_{2} \mathrm{Cl}_{2}(30 \mathrm{~mL})$ and $\mathrm{MeCN}(0.5 \mathrm{~mL})$, and the reaction mixture was stirred in the dark for $45 \mathrm{~min}$. The solvent was evaporated under reduced pressure to dryness, the residue extracted with $\mathrm{CH}_{2} \mathrm{Cl}_{2}(20 \mathrm{~mL})$, and filtered off the white solid $(\mathrm{AgBr}) . N$-MeIm $(13 \mu \mathrm{L}$, $0.25 \mathrm{mmol}$ ) was added to the resulting dark orange solution, and the mixture was stirred for $1 \mathrm{~h}$ at room temperature. Then, the solution was concentrated under reduced pressure to a volume of $10 \mathrm{~mL}$, and addition of hexane $(20 \mathrm{~mL})$ caused the precipitation of a red solid that was washed with hexane $(2 \times 20 \mathrm{~mL})$. Compound 1 was obtained as a red microcrystalline solid. Yield: $121 \mathrm{mg}(82 \%)$. IR $\left(\mathrm{CH}_{2} \mathrm{Cl}_{2}, \mathrm{~cm}^{-1}\right): 1951,1867\left(v_{\mathrm{CO}}\right) .{ }^{1} \mathrm{H}$ $\operatorname{NMR}\left(\mathrm{CD}_{2} \mathrm{Cl}_{2}\right): \delta 8.86$ (m, 2H, bipy), 8.51 (m, 2H, bipy), 8.22 (m, 2H, bipy), 7.65 (m, $2 \mathrm{H}$, bipy), 7.27 (s, $1 \mathrm{H}, \mathrm{NCHN} N$-MeIm), $6.81\left(\mathrm{~s}_{\mathrm{br}}, 1 \mathrm{H}, \mathrm{CH}\right.$-MeIm), $6.28\left(\mathrm{~s}_{\mathrm{br}}, 1 \mathrm{H}, \mathrm{CH}\right.$ $N$-MeIm), 3.59 (s, 3H, CH $N$-MeIm), 3.08 (s, 2H, $\left.\mathrm{H}_{s y n} \eta^{3}-\mathrm{C}_{4} \mathrm{H}_{7}\right), 2.11\left(\mathrm{~s}, 2 \mathrm{H}, \mathrm{H}_{\text {anti }} \eta^{3}-\right.$ $\left.\mathrm{C}_{4} \mathrm{H}_{7}\right), 1.03\left(\mathrm{~s}, 3 \mathrm{H}, \mathrm{CH}_{3} \eta^{3}-\mathrm{C}_{4} \mathrm{H}_{7}\right) \cdot{ }^{13} \mathrm{C}\left\{{ }^{1} \mathrm{H}\right\} \operatorname{NMR}\left(\mathrm{CD}_{2} \mathrm{Cl}_{2}\right): \delta 225.6(\mathrm{CO}), 154.1,152.3$, 140.8, 127.6, 124.7 (bipy), 139.7 (NCHN, $N$-MeIm), 128.8, 122.6 (CH $N$-MeIm), 84.1 $\left(C_{2} \eta^{3}-\mathrm{C}_{4} \mathrm{H}_{7}\right), 56.6\left(C_{1}\right.$ and $\left.C_{3} \eta^{3}-\mathrm{C}_{4} \mathrm{H}_{7}\right), 34.9\left(\mathrm{CH}_{3} N\right.$-MeIm $), 18.8\left(\mathrm{CH}_{3} \eta^{3}-\mathrm{C}_{4} \mathrm{H}_{7}\right)$. Anal. Calcd. for $\mathrm{C}_{21} \mathrm{H}_{21} \mathrm{~F}_{3} \mathrm{MoN}_{4} \mathrm{O}_{5} \mathrm{~S}$ : C 42.43, H 3.56, N 9.42. Found: C 42.87, H 3.66, N 9.21.

Synthesis of $\left[\mathrm{Mo}\left(\eta^{3}-\mathrm{C}_{4} \mathrm{H}_{7}\right)(\right.$ bipy $)(\mathrm{CO})_{2}(\mathrm{~N}$-MesIm) $] \mathrm{OTf}$ (2). Compound 2 was prepared as described above for compound 1 starting from $\left[\mathrm{MoCl}\left(\eta^{3}-\mathrm{C}_{4} \mathrm{H}_{7}\right)(\right.$ bipy $\left.)(\mathrm{CO})_{2}\right]$ (100 mg, $0.25 \mathrm{mmol}), \operatorname{AgOTf}(65 \mathrm{mg}, 0.25 \mathrm{mmol})$ and $N$-MesIm $(47 \mathrm{mg}, 0.25 \mathrm{mmol})$. Compound 2 was obtained as an orange microcrystalline solid. Yield: $148 \mathrm{mg}(85 \%)$. IR $\left(\mathrm{CH}_{2} \mathrm{Cl}_{2}, \mathrm{~cm}^{-1}\right): 1954,1869\left(v_{\mathrm{CO}}\right) .{ }^{1} \mathrm{H}$ NMR $\left(\mathrm{CD}_{2} \mathrm{Cl}_{2}\right): \delta 8.93$ (m, 2H, bipy), 8.57 (m, $2 \mathrm{H}$, bipy), 8.25 (m, 2H, bipy), 7.68 (m, 2H, bipy), 7.36 (s, $1 \mathrm{H}, \mathrm{NC} H \mathrm{~N} N$-MesIm), 6.95 (s, 2H, Mes), $6.79\left(\mathrm{~s}_{\mathrm{br}}, 1 \mathrm{H}, \mathrm{CH} N\right.$-MesIm), $6.27\left(\mathrm{~s}_{\mathrm{br}}, 1 \mathrm{H}, \mathrm{CH} N\right.$-MesIm), $3.16(\mathrm{~s}, 2 \mathrm{H}$, $\left.\mathrm{H}_{s y n} \eta^{3}-\mathrm{C}_{4} \mathrm{H}_{7}\right), 2.30\left(\mathrm{~s}, 3 \mathrm{H}, \mathrm{CH}_{3} N\right.$-MesIm), $1.71\left(\mathrm{~s}, 8 \mathrm{H}, 2 \times \mathrm{CH}_{3} N\right.$-MesIm and $\mathrm{H}_{\text {anti }} \eta^{3}$ $\left.\mathrm{C}_{4} \mathrm{H}_{7}\right), 1.09$ (s, $\left.3 \mathrm{H}, \mathrm{CH}_{3} \eta^{3}-\mathrm{C}_{4} \mathrm{H}_{7}\right) \cdot{ }^{13} \mathrm{C}\left\{{ }^{1} \mathrm{H}\right\} \operatorname{NMR}\left(\mathrm{CD}_{2} \mathrm{Cl}_{2}\right): \delta 227.5(\mathrm{CO}), 156.1,154.2$, 143.2, 131.7, 126.8 (bipy), 142.7, 133.8, 130.3, 129.8 (N-MesIm), 141.4 (NCHN, $N$ MesIm), 136.9, $124.9\left(C \mathrm{H} \mathrm{N}\right.$-MesIm), $86.5\left(C_{2} \eta^{3}-\mathrm{C}_{4} \mathrm{H}_{7}\right), 59.0\left(C_{1}\right.$ and $\left.C_{3} \eta^{3}-\mathrm{C}_{4} \mathrm{H}_{7}\right)$, $23.1\left(\mathrm{CH}_{3} N\right.$-MesIm), $21.0\left(\mathrm{CH}_{3} \eta^{3}-\mathrm{C}_{4} \mathrm{H}_{7}\right), 19.2\left(2 \times \mathrm{CH}_{3} N\right.$-MesIm $)$. Anal. Calcd. for $\mathrm{C}_{29} \mathrm{H}_{29} \mathrm{~F}_{3} \mathrm{MoN}_{4} \mathrm{O}_{5} \mathrm{~S}$ : C 49.90, H 4.18, N 8.02. Found: C 49.67, H 4.32, N 8.15.

Synthesis of $\left[\mathrm{Mo}\left(\boldsymbol{\eta}^{3}-\mathbf{C}_{4} \mathrm{H}_{7}\right)(\right.$ bipy $)(\mathbf{C O})_{2}\left(\boldsymbol{C}\right.$-MeIm) $\mathbf{( 3 )}$. $\mathrm{KN}\left(\mathrm{SiMe}_{3}\right)_{2}(0.20 \mathrm{~mL}$ of a 0.5 $\mathrm{M}$ solution in toluene, $0.100 \mathrm{mmol}$ ) was added to a solution of compound $\mathbf{1}(50 \mathrm{mg}$, $0.084 \mathrm{mmol})$ in thf $(20 \mathrm{~mL})$ previously cooled to $-78^{\circ} \mathrm{C}$, and the mixture was allowed to reach room temperature. The solvent was evaporated to dryness, the residue extracted with toluene $(20 \mathrm{~mL})$ and filtered via canula. The solution was concentrated under reduced pressure to a volume of $5 \mathrm{~mL}$, and addition of hexane $(20 \mathrm{~mL})$ caused the precipitation of a dark red solid that was washed with hexane $(2 \times 20 \mathrm{~mL})$. Yield: $32 \mathrm{mg}$ (86 \%). IR $\left(\mathrm{CH}_{2} \mathrm{Cl}_{2}, \mathrm{~cm}^{-1}\right): 1923,1839\left(v_{\mathrm{CO}}\right) .{ }^{1} \mathrm{H}$ NMR $\left(\mathrm{CD}_{2} \mathrm{Cl}_{2}\right): \delta 8.57$ (m, 2H, bipy), 8.19 (m, 2H, bipy), 7.92 (m, 2H, bipy), 7.34 (m, 2H, bipy), 6.71 ( $\mathrm{s}_{\mathrm{br}}, 1 \mathrm{H}, \mathrm{CH} \mathrm{N}$-MeIm), $6.38\left(\mathrm{~s}_{\mathrm{br}}, 1 \mathrm{H}, \mathrm{CH} N\right.$-MeIm), $4.15\left(\mathrm{~s}, 3 \mathrm{H}, \mathrm{CH}_{3} N\right.$-MeIm), $2.87\left(\mathrm{~s}, 2 \mathrm{H}, \mathrm{H}_{s y n} \eta^{3}-\mathrm{C}_{4} \mathrm{H}_{7}\right), 1.68$ (s, $\left.2 \mathrm{H}, \mathrm{H}_{\text {anti }} \eta^{3}-\mathrm{C}_{4} \mathrm{H}_{7}\right), 0.93$ (s, $3 \mathrm{H}, \mathrm{CH}_{3} \eta^{3}-\mathrm{C}_{4} \mathrm{H}_{7}$ ). Anal. Calcd. for $\mathrm{C}_{20} \mathrm{H}_{20} \mathrm{MoN}_{4} \mathrm{O}_{2}: \mathrm{C}$ 54.06, H 4.54, N 12.61. Found: C 54.40, H 4.11, N 12.23.

Synthesis of $\left[\mathrm{Mo}\left(\eta^{3}-\mathrm{C}_{4} \mathrm{H}_{7}\right)(\text { bipy)(CO) })_{2}(C\right.$-MesIm)] (4). Compound 4 was prepared as described above for compound 3 starting from compound $2(50 \mathrm{mg}, 0.072 \mathrm{mmol})$ and $\mathrm{KN}\left(\mathrm{SiMe}_{3}\right)_{2}(0.17 \mathrm{~mL}$ of a $0.5 \mathrm{M}$ solution in toluene, $0.085 \mathrm{mmol})$. Slow diffusion of hexane $(20 \mathrm{~mL})$ into a concentrated solution in toluene at $-20{ }^{\circ} \mathrm{C}$ afforded red crystals of 4. Yield: $33 \mathrm{mg}(85 \%)$. IR (thf, $\left.\mathrm{cm}^{-1}\right): 1931,1851\left(v_{\mathrm{CO}}\right)$. ${ }^{1} \mathrm{H}$ NMR $\left(\mathrm{CD}_{2} \mathrm{Cl}_{2}\right): \delta 8.47(\mathrm{~m}$, $2 \mathrm{H}$, bipy), 8.16 (m, 2H, bipy), 7.94 ( $\mathrm{m}, 2 \mathrm{H}$, bipy), 7.35 ( $\mathrm{m}, 2 \mathrm{H}$, bipy), 6.89 (s, 2H, Mes), $6.66\left(\mathrm{~s}, 1 \mathrm{H}, \mathrm{CH}\right.$-MesIm), $6.56\left(\mathrm{~s}, 1 \mathrm{H}, \mathrm{CH}\right.$-MesIm), $2.72\left(\mathrm{~s}, 2 \mathrm{H}, \mathrm{H}_{s y n} \eta^{3}-\mathrm{C}_{4} \mathrm{H}_{7}\right), 2.34$ (s, 3H, $\mathrm{CH}_{3} C$-MesIm), 1.80 (s, 6H, 2×CH $C$-MesIm), $1.38\left(\mathrm{~s}, 2 \mathrm{H}, \mathrm{H}_{\text {anti }} \eta^{3}-\mathrm{C}_{4} \mathrm{H}_{7}\right), 0.80$ (s, $\left.3 \mathrm{H}, \mathrm{CH}_{3} \eta^{3}-\mathrm{C}_{4} \mathrm{H}_{7}\right) .{ }^{13} \mathrm{C}\left\{{ }^{1} \mathrm{H}\right\}$ NMR $\left(\mathrm{CD}_{2} \mathrm{Cl}_{2}\right): \delta 231.2(\mathrm{CO}), 184.5$ (Mo-C), 156.9, $154.3,139.3,130.5,123.7$ (bipy), 141.5, 139.5, 126.9, 126.1 (C-MesIm), 130.2 (CH $C$ MesIm), 122.7 (CH $C$-MesIm), $87.0\left(C_{2} \eta^{3}-\mathrm{C}_{4} \mathrm{H}_{7}\right), 59.2\left(C_{1}\right.$ and $\left.C_{3} \eta^{3}-\mathrm{C}_{4} \mathrm{H}_{7}\right), 23.2\left(C_{3}\right.$ $C$-MesIm), $20.4 \quad\left(\mathrm{CH}_{3} \quad \eta^{3}-\mathrm{C}_{4} \mathrm{H}_{7}\right), \quad 20.3 \quad\left(2 \times \mathrm{CH}_{3} \quad C\right.$-MesIm). Anal. Calcd. for $\mathrm{C}_{28} \mathrm{H}_{28} \mathrm{MoN}_{4} \mathrm{O}_{2}$ : C 61.31, H 5.14, N 10.21. Found: C 60.99, H 5.04, N 10.36.

Synthesis of $\left[\mathrm{Mo}\left(\eta^{3}-\mathrm{C}_{4} \mathrm{H}_{7}\right)\left(\right.\right.$ bipy)$\left.(\mathbf{C O})_{2}(\mathrm{HN}-\mathrm{NHC}-\mathrm{Me})\right] \mathrm{OTf}$ (5). $\mathrm{KN}\left(\mathrm{SiMe}_{3}\right)_{2}(0.20$ $\mathrm{mL}$ of a $0.5 \mathrm{M}$ solution in toluene, $0.100 \mathrm{mmol}$ ) was added to a solution of compound 1 $(50 \mathrm{mg}, 0.084 \mathrm{mmol})$ in thf $(20 \mathrm{~mL})$ previously cooled to $-78^{\circ} \mathrm{C}$, and the mixture was allowed to reach room temperature. The solvent was evaporated to dryness, the residue extracted with toluene $(20 \mathrm{~mL})$ and filtered via canula. HOTf $(7 \mu \mathrm{L}, 0.084 \mathrm{mmol})$ was added and the reaction mixture was stirred at room temperature for $30 \mathrm{~min}$. The solution was concentrated under reduced pressure to a volume of $5 \mathrm{~mL}$, and addition of hexane $(20 \mathrm{~mL})$ caused the precipitation of a red solid that was washed with hexane $(2 \times 20$ $\mathrm{mL})$. Yield: $39 \mathrm{mg}(78 \%)$. IR $\left(\mathrm{CH}_{2} \mathrm{Cl}_{2}, \mathrm{~cm}^{-1}\right): 1950,1866\left(v_{\mathrm{CO}}\right) .{ }^{1} \mathrm{H}$ NMR $\left(\mathrm{CD}_{2} \mathrm{Cl}_{2}\right): \delta$ $10.09\left(\mathrm{~s}_{\mathrm{br}}, 1 \mathrm{H}, \mathrm{N} H\right), 8.96$ (m, 2H, bipy), 8.25 (m, 2H, bipy), 8.12 (m, 2H, bipy), 7.68 (m, $2 \mathrm{H}$, bipy), 6.98 (s, 1H, CH HN-NHC-Me), 6.78 (s, 1H, CH HN-NHC-Me), 3.58 (s, 3H, $\left.\mathrm{CH}_{3} \mathrm{HN}-\mathrm{NHC}-\mathrm{Me}\right), 3.17$ (s, 2H, $\left.\mathrm{H}_{\text {syn }} \eta^{3}-\mathrm{C}_{4} \mathrm{H}_{7}\right), 1.90\left(\mathrm{~s}, 2 \mathrm{H}, \mathrm{H}_{\text {anti }} \eta^{3}-\mathrm{C}_{4} \mathrm{H}_{7}\right), 0.92(\mathrm{~s}, 3 \mathrm{H}$, $\left.\mathrm{CH}_{3} \eta^{3}-\mathrm{C}_{4} \mathrm{H}_{7}\right) .{ }^{13} \mathrm{C}\left\{{ }^{1} \mathrm{H}\right\}$ NMR $\left(\mathrm{CD}_{2} \mathrm{Cl}_{2}\right): \delta 225.6(\mathrm{CO}), 184.6(\mathrm{Mo}-\mathrm{C}), 153.3,152.7$, 139.1, 127.1, 123.4, 122.8, 120.1 (bipy and $2 \times C \mathrm{H}$ HN-NHC-Me), $88.0\left(C_{2} \eta^{3}-\mathrm{C}_{4} \mathrm{H}_{7}\right)$, 58.6 $\left(C_{1}\right.$ and $\left.C_{3} \eta^{3}-\mathrm{C}_{4} \mathrm{H}_{7}\right), 37.8\left(\mathrm{CH}_{3} \mathrm{HN}-\mathrm{NHC}-\mathrm{Me}\right), 17.7\left(\mathrm{CH}_{3} \eta^{3}-\mathrm{C}_{4} \mathrm{H}_{7}\right)$. Anal. Calcd. for $\mathrm{C}_{21} \mathrm{H}_{21} \mathrm{~F}_{3} \mathrm{MoN}_{4} \mathrm{O}_{5} \mathrm{~S}$ : C 42.43, H 3.56, N 9.42. Found: C 42.51, H 3.62, N 9.38.

Synthesis of $\left[\mathrm{Mo}\left(\eta^{3}-\mathrm{C}_{4} \mathrm{H}_{7}\right)(\text { bipy)(CO) })_{2}(\mathrm{MeN}-\mathrm{NHC}-\mathrm{Mes})\right] \mathrm{OTf}(\mathbf{8}) . \mathrm{KN}\left(\mathrm{SiMe}_{3}\right)_{2}(0.17$ $\mathrm{mL}$ of a $0.5 \mathrm{M}$ solution in toluene, $0.085 \mathrm{mmol}$ ) was added to a solution of compound 2 $(50 \mathrm{mg}, 0.072 \mathrm{mmol})$ in thf $(20 \mathrm{~mL})$ previously cooled to $-78{ }^{\circ} \mathrm{C}$, and the mixture was allowed to reach room temperature. The solvent was evaporated to dryness, the residue extracted with toluene $(20 \mathrm{~mL})$ and filtered via canula. MeOTf $(10 \mu \mathrm{L}, 0.091 \mathrm{mmol})$ was added and the reaction mixture was stirred at room temperature for $30 \mathrm{~min}$. The solution was concentrated under reduced pressure to a volume of $5 \mathrm{~mL}$, and addition of hexane $(20 \mathrm{~mL})$ caused the precipitation of a red solid that was washed with hexane (2 $\times 20 \mathrm{~mL})$. Compound 8 was obtained as a red solid. Yield: $50 \mathrm{mg}(83 \%)$. IR $\left(\mathrm{CH}_{2} \mathrm{Cl}_{2}\right.$, $\left.\mathrm{cm}^{-1}\right): 1946,1865\left(v_{\mathrm{CO}}\right) .{ }^{1} \mathrm{H}$ NMR $\left(\mathrm{CD}_{2} \mathrm{Cl}_{2}\right): \delta 8.32$ (m, 2H, bipy), 8.12 (m, 4H, bipy), 7.33 (m, 2H, bipy), 7.19 (s, 1H, CH MeN-NHC-Mes), 6.76 (s, 2H, Mes), 6.65 (s, 1H, 
CH MeN-NHC-Mes), 3.98 (s, 3H, N-CH $H_{3}$ MeN-NHC-Mes) 3.02 (s, 2H, $\mathrm{H}_{s y n} \eta^{3}-\mathrm{C}_{4} \mathrm{H}_{7}$ ), 2.39 (s, 3H, CH $H_{3}$ MeN-NHC-Mes), 1.64 (s, $\left.2 \mathrm{H}, \mathrm{H}_{\text {anti }} \eta^{3}-\mathrm{C}_{4} \mathrm{H}_{7}\right), 1.55$ (s, $6 \mathrm{H}, 2 \times \mathrm{CH}_{3}$ MeN-NHC-Mes), 0.60 (s, 3H, $\left.\mathrm{CH}_{3} \eta^{3}-\mathrm{C}_{4} \mathrm{H}_{7}\right) .{ }^{13} \mathrm{C}\left\{{ }^{1} \mathrm{H}\right\}$ NMR $\left(\mathrm{CD}_{2} \mathrm{Cl}_{2}\right): \delta 227.6(\mathrm{CO})$, 186.7 (Mo-C), 156.1, 155.6, 142.2, 131.7, 125.2 (bipy), 141.5, 136.2, 121.4, 119.9 (MeN-NHC-Mes), 128.8, $121.7\left(C \mathrm{H} \mathrm{MeN-NHC-Mes),} 90.4\left(C_{2} \eta^{3}-\mathrm{C}_{4} \mathrm{H}_{7}\right), 62.8\left(C_{1}\right.\right.$ and $\left.C_{3} \eta^{3}-\mathrm{C}_{4} \mathrm{H}_{7}\right), 42.6$ (N-CH $\left.\mathrm{H}_{3} \mathrm{MeN}-\mathrm{NHC}-\mathrm{Mes}\right), 23.3\left(\mathrm{CH}_{3} \mathrm{MeN}-\mathrm{NHC}-\mathrm{Mes}\right), 20.3\left(2 \times \mathrm{CH}_{3}\right.$ MeN-NHC-Mes), $19.1\left(\mathrm{CH}_{3} \eta^{3}-\mathrm{C}_{4} \mathrm{H}_{7}\right)$. Anal. Calcd. for $\mathrm{C}_{30} \mathrm{H}_{31} \mathrm{~F}_{3} \mathrm{MoN}_{4} \mathrm{O}_{5} \mathrm{~S}: \mathrm{C} 50.56, \mathrm{H}$ 4.38, N 7.86. Found: C 50.61, H 4.32, N 7.79.

Synthesis of $\left[\mathrm{Mo}\left(\eta^{3}-\mathrm{C}_{4} \mathrm{H}_{7}\right)(\mathrm{bipy})(\mathrm{CO})_{2}(\right.$ Et-NHC-Me)]OTf (9). Compound 9 was prepared as described above for compound 8 starting from $1(50 \mathrm{mg}, 0.084 \mathrm{mmol})$, $\mathrm{KN}\left(\mathrm{SiMe}_{3}\right)_{2}(0.20 \mathrm{~mL}$ of a $0.5 \mathrm{M}$ solution in toluene, $0.100 \mathrm{mmol})$ and EtOTf $(11 \mu \mathrm{L}$ $0.085 \mathrm{mmol})$. Slow diffusion of hexane $(20 \mathrm{~mL})$ into a concentrated solution in $\mathrm{CH}_{2} \mathrm{Cl}_{2}$ at $-20{ }^{\circ} \mathrm{C}$ afforded red crystals of $\mathbf{9}$, one of which was used for an $\mathrm{X}$-ray analysis. Yield $44 \mathrm{mg}(84 \%)$. IR $\left(\mathrm{CH}_{2} \mathrm{Cl}_{2}, \mathrm{~cm}^{-1}\right): 1947,1866\left(v_{\mathrm{CO}}\right) .{ }^{1} \mathrm{H}$ NMR $\left(\mathrm{CD}_{2} \mathrm{Cl}_{2}\right): \delta 8.98(\mathrm{~m}, 2 \mathrm{H}$ bipy), 8.53 (m, 2H, bipy), 8.20 (m, 2H, bipy), 7.65 (m, 2H, bipy), 6.91 (s, $1 \mathrm{H}, \mathrm{CH}$ EtNHC-Me), 6.87 (s, 1H, CH Et-NHC-Me), 3.91 (q ( $\left.J=7.3 \mathrm{~Hz}), 2 \mathrm{H} \mathrm{CH} \mathrm{H}_{2} E t-\mathrm{NHC}-\mathrm{Me}\right)$, $3.40\left(\mathrm{~s}, 3 \mathrm{H}, \mathrm{CH}_{3}\right.$ Et-NHC-Me), $3.36\left(\mathrm{~s}, 2 \mathrm{H}, \mathrm{H}_{s y n} \eta^{3}-\mathrm{C}_{4} \mathrm{H}_{7}\right), 1.92\left(\mathrm{~s}, 2 \mathrm{H}, \mathrm{H}_{\text {anti }} \eta^{3}-\mathrm{C}_{4} \mathrm{H}_{7}\right)$ 0.97 (t $(J=7.3 \mathrm{~Hz}), \mathrm{CH}_{3} E t$-NHC-Me), $0.91\left(\mathrm{~s}, 3 \mathrm{H}, \mathrm{CH}_{3} \eta^{3}-\mathrm{C}_{4} \mathrm{H}_{7}\right) \cdot{ }^{13} \mathrm{C}\left\{{ }^{1} \mathrm{H}\right\}$ NMR $\left(\mathrm{CD}_{2} \mathrm{Cl}_{2}\right): \delta 225.2(\mathrm{CO}), 185.3$ (Mo-C), 154.2, 152.7, 140.0, 126.2, 124.2 (bipy), 124.4 121.3 (CH Et-NHC-Me), $88.6\left(C_{2} \eta^{3}-\mathrm{C}_{4} \mathrm{H}_{7}\right), 59.7\left(C_{1}\right.$ and $\left.C_{3} \eta^{3}-\mathrm{C}_{4} \mathrm{H}_{7}\right), 45.8\left(C_{2}\right.$ EtNHC-Me), $39.0\left(\mathrm{CH}_{3}\right.$ Et-NHC-Me $), 17.2\left(\mathrm{CH}_{3} \eta^{3}-\mathrm{C}_{4} \mathrm{H}_{7}\right), 16.1\left(\mathrm{CH}_{3}\right.$ Et-NHC-Me $)$. Anal. Calcd. for $\mathrm{C}_{23} \mathrm{H}_{25} \mathrm{~F}_{3} \mathrm{~N}_{4} \mathrm{MoO}_{5} \mathrm{~S}$ : C 44.38, H 4.05, N 9.00. Found: C 44.05, H 3.86, N 8.69.

Synthesis of $\left[\mathrm{Mo}\left(\boldsymbol{\eta}^{3}-\mathrm{C}_{\mathbf{4}} \mathrm{H}_{7}\right)(\right.$ bipy $\left.)(\mathbf{C O})_{2}(\mathrm{MeN}-\mathrm{NHC}-\mathrm{Au})\right] \mathrm{OTf}(\mathbf{1 0}) . \mathrm{KN}\left(\mathrm{SiMe}_{3}\right)_{2}(0.20$ $\mathrm{mL}$ of a $0.5 \mathrm{M}$ solution in toluene, $0.100 \mathrm{mmol}$ ) was added to a solution of compound 1 $(50 \mathrm{mg}, 0.084 \mathrm{mmol})$ in thf $(20 \mathrm{~mL})$ previously cooled to $-78{ }^{\circ} \mathrm{C}$, and the mixture was allowed to reach room temperature. The solvent was evaporated to dryness, the residue extracted with toluene $(20 \mathrm{~mL})$ and filtered via canula. [AuCl$\left.\left(\mathrm{PPh}_{3}\right)\right](42 \mathrm{mg}, 0.084$ $\mathrm{mmol}$ ) was added and the reaction mixture was stirred at room temperature for $30 \mathrm{~min}$. The solution was concentrated under reduced pressure to a volume of $5 \mathrm{~mL}$, and addition of hexane $(20 \mathrm{~mL})$ caused the precipitation of a dark red solid that was washed with hexane $(2 \times 20 \mathrm{~mL})$. Slow diffusion of hexane $(20 \mathrm{~mL})$ into a concentrated solution in $\mathrm{CH}_{2} \mathrm{Cl}_{2}$ afforded red crystals of 10. Yield: $72 \mathrm{mg}(81 \%)$. IR $\left(\mathrm{CH}_{2} \mathrm{Cl}_{2}, \mathrm{~cm}^{-1}\right)$ : 1946, $1860\left(v_{\mathrm{CO}}\right) .{ }^{1} \mathrm{H}$ NMR $\left(\mathrm{CD}_{2} \mathrm{Cl}_{2}\right): \delta 8.78$ (m, 2H, bipy), 8.37 (m, 2H, bipy), 8.10 (m, 2H, bipy), $7.69\left(\mathrm{~m}, 15 \mathrm{H}, \mathrm{PPh}_{3}\right), 7.17$ (m, 2H, bipy), 6.76 (s, 1H, CH MeN-NHC-Au), 5.90 (s, 1H, CH MeN-NHC-Au), 3.75 (s, 3H CH $\left.\mathrm{MeN}_{3} \mathrm{NHC}-\mathrm{Au}\right), 3.00$ (s, 2H, $\mathrm{H}_{s y n} \eta^{3}-$ $\left.\mathrm{C}_{4} \mathrm{H}_{7}\right), 1.62\left(\mathrm{~s}, 2 \mathrm{H}, \mathrm{H}_{\text {anti }} \eta^{3}-\mathrm{C}_{4} \mathrm{H}_{7}\right), 1.03\left(\mathrm{~s}, 3 \mathrm{H}, \mathrm{CH}_{3} \eta^{3}-\mathrm{C}_{4} \mathrm{H}_{7}\right) .{ }^{31} \mathrm{P}\left\{{ }^{1} \mathrm{H}\right\} \mathrm{NMR}\left(\mathrm{CD}_{2} \mathrm{Cl}_{2}\right)$ : $\delta$ 41.1. ${ }^{13} \mathrm{C}\left\{{ }^{1} \mathrm{H}\right\} \operatorname{NMR}\left(\mathrm{CD}_{2} \mathrm{Cl}_{2}\right): \delta 225.9(\mathrm{CO}), 189.9\left(\mathrm{~d}\left({ }^{2} J_{\mathrm{C}, \mathrm{P}}=135.6 \mathrm{~Hz}\right), \mathrm{Au}-\mathrm{C}\right), 153.8$ 151.8, 139.9, 126.3, 123.8 (bipy), $134.2\left(\mathrm{~d}\left({ }^{2} J_{\mathrm{C}, \mathrm{P}}=13.6 \mathrm{~Hz}\right), \mathrm{C}_{o} \mathrm{PPh}_{3}\right), 132.1(2 \times C \mathrm{H}$ MeN-NHC-Au), 129.6 (d ( $\left.\left.{ }^{3} J_{C, \mathrm{P}}=11.1 \mathrm{~Hz}\right), \mathrm{C}_{m} \mathrm{PPh}_{3}\right), 129.5\left(\mathrm{~d}\left({ }^{1} J_{\mathrm{C}, \mathrm{P}}=72.8 \mathrm{~Hz}\right), \mathrm{C}_{i} \mathrm{PPh}_{3}\right)$, $120.7\left(\mathrm{C}_{p} \mathrm{PPh}_{3}\right), 83.5\left(C_{2} \eta^{3}-\mathrm{C}_{4} \mathrm{H}_{7}\right), 56.6\left(C_{1}\right.$ and $\left.C_{3} \eta^{3}-\mathrm{C}_{4} \mathrm{H}_{7}\right), 36.6\left(\mathrm{CH}_{3} \mathrm{MeN}-\mathrm{NHC}-\right.$ $\mathrm{Au})$, $18.6\left(\mathrm{CH}_{3} \eta^{3}-\mathrm{C}_{4} \mathrm{H}_{7}\right)$. Anal. Calcd. for $\mathrm{C}_{39} \mathrm{H}_{35} \mathrm{AuF}_{3} \mathrm{MoN}_{4} \mathrm{O}_{5}$ PS: C 44.50, H 3.35, N 5.32. Found: C 44.33, H 3.31, N 5.41.

\section{Acknowledgements}

Financial support from the Ministerio de Ciencia e Innovación (MICINN, project number CTQ2009-12366 ) and Principado de Asturias (project number IB08-104) is gratefully acknowledged.

$¥ \quad$ Socrates-Erasmus exchange student from Heidelberg University

[1] For reviews on N-heterocyclic carbenes, see for example: a) W. A. Herrmann Angew. Chem. 2002, 114, 1342-1363; Angew. Chem. Int. Ed. 2002, 41, 1290 1309; b) F. E. Hahn, M. C. Jahnke, Angew. Chem. 2008, 120, 3166-3216; Angew. Chem. Int. Ed. 2008, 47, 3122-3172; c) O. Schuster, L. Yang, H. G. Raubenheimer, M. Albrecht, Chem. Rev. 2009, 109, 3445-3478; d) M. Poyatos, J. A. Mata, E. Peris, Chem. Rev. 2009, 109, 3677-3707 ; d) There are two special issues dedicated to recent developments in the organometallic chemistry of $\mathrm{N}$ heterocyclic carbenes, see: Coord. Chem. Rev. 2007, 251, 595-896.

[2] A. J. Arduengo III, R. L. Harlow, M. Kline, J. Am. Chem. Soc. 1991, 113, 361363 .

[3] See reference $1 \mathrm{~b}$ and references therein.

[4] a) K. Denk, P. Sirsch, W. A. Herrmann, J. Organomet. Chem. 2002, 649, 219 224; b) T. M. Trnka, J. P. Morgan, M. S. Sandford, T. E. Wilhelm, M. Scholl, T.-L. Choi, S. M. Ding, M. W. Day, R. H. Grubbs, J. Am. Chem. Soc. 2003, 125, 2546-2558. c) Y. Yamaguchi, T. Kashiwabara, K. Ogata, Y. Miura, Y. Nakamura, K. Kobayashi, T. Ito, Chem. Commun. 2004, 2160-2161.

[5] I. J. B. Lin, C. S. Vasam, Coord. Chem. Rev. 2007, 251, 642-670.

[6] There are just a couple of examples of imidazole to NHC tautomerization: a) R J. Sundberg, R. F. Bryan, I. F. Taylor Jr, H. Taube, J. Am. Chem. Soc. 1974, 96 381-392; b) K. L. Tan, R. G. Bergman, J. A. Ellman, J. Am. Chem. Soc. 2002, 124, 3202-3203. This kind of tautomerization aided by chelate ring formation can be found in: c) V. Miranda-Soto, D. B. Grotjahn, A. G. DiPasquale, A. L. Rheingold, J. Am. Chem. Soc. 2008, 130, 13200-13201 ; d) K. Araki, S. Kuwata, T. Ikariya, Organometallics 2008, 27, 2176-2178.

[7] NHC to imidazole tautomerization: a) S. Burling, M. F. Mahon, R. E. Powell, M K. Whittlesey, J. M. J. Williams, J. Am. Chem. Soc. 2006, 128, 13702-13703; b) X. Wang, H. Chen, X. Li, Organometallics 2007, 26, 4684-4687.

[8] J. Ruiz, B. F. Perandones, J. Am. Chem. Soc. 2007, 129, 9298-9299.

[9] M. A. Huertos, J. Pérez, L. Riera, J. Am. Chem. Soc. 2008, 130, 5662-5663.

[10] J. Ruiz, B. F. Perandones, J. F. Van der Maelen, S. García-Granda, Organometallics 2010, 29, 4639-4642.

[11] See, for example: a) J. Pérez, D. Morales, S. Nieto, L. Riera, V. Riera, D. Miguel, Dalton Trans. 2005, 884-888; b) L Ion, D. Morales, S. Nieto, J. Perez, L. Riera, V. Riera, D. Miguel, R. A. Kowenicki, M. McPartlin, Inorg. Chem. 2007, 46, 2846-2853.

[12] a) A. Wacker, H. Pritzkow, W. Siebert, Eur. J. Inorg. Chem. 1998, 843-849; b) D. Vagedes, G. Kehr, D. König, K. Wedeking, R. Fröhlich, G. Erker, C. MückLichtenfeld, S. Grimme, Eur. J. Inorg. Chem. 2002, 2015-2021; c) O. Kaufhold, A. Stasch, T. Pape, A. Hepp, P. G. Edwards, P. D. Newman, F. E. Hahn, J. Am. Chem. Soc. 2009, 131, 306-317; d) J. Ruiz, A. Berros, B. F. Perandones, M. Vivanco, Dalton Trans. 2009, 6999-7007.

[13] a) M. A. Huertos, J. Pérez, L. Riera, A. Menéndez-Velázquez, J. Am. Chem. Soc. 2008, 130, 13530-13531; b) M. A. Huertos, J. Pérez, L. Riera, J. Díaz, R. López, Chem. Eur. J. 2010, 16, 8495-8507.

[14] Selected crystallographic data for 4: $\mathrm{C}_{28} \mathrm{H}_{28} \mathrm{MoN}_{4} \mathrm{O}_{2}, M=548.48$, triclinic, $\mathrm{P}-1$, $a=10.249(1) \AA, b=11.156(1) \AA, c=12.019(2) \AA, \alpha=64.658(4)^{\circ}, \beta=$ $83.164(6)^{\circ}, \gamma=81.727(4)^{\circ}, 100.0(1) \mathrm{K}, V=1226.5(4) \AA^{3}, Z=2.16470$ reflections measured, 4892 independent $($ Rint $=0.1566) . R_{1}=0.0700, \mathrm{w} R_{2}=$ 0.1615 (all data)

[15] a) D. M. Anderson, G. S. Bristow, P. B. Hitchcock, H. A. Jasim, M. F. Lappert, B. W. Skelton, J. Chem. Soc., Dalton Trans. 1987, 2843-2851; b) Y. Yamaguchi,R. Oda, K. Sado, K. Kobayashi, M. Minato, T. Ito, Bull. Chem. Soc. Jpn. 2003, 76, 991-997; c) K. Ogata, Y. Yamaguchi, T. Kashiwabara, T. Ito, J. Organomet. Chem. 2005, 690, 5701-5709; d) F. Wu, V. K. Dioumaev, D. J. Szalda, J. Hanson, R. M. Bullock, Organometallics 2007, 26, 5079-5090; e) V. V. K. M. Kandepi, A. Pontes da Costa, E. Peris, B. Royo, Organometallics 2009 28, 4544-4549; f) D. Takaki, T. Okayama, H. Shuto, S. Matsumoto, Y. Yamaguchi, S. Matsumoto Dalton Trans. 2011, 40, 1445-1447.

[16] Selected crystallographic data for 6: $\mathrm{C}_{29} \mathrm{H}_{29} \mathrm{~F}_{3} \mathrm{MoN}_{4} \mathrm{O}_{5} \mathrm{~S}, M=698.56$, triclinic, $\mathrm{P}-1, a=8.9936(4) \AA, b=12.8750(6) \AA, c=14.3875(7) \AA, \alpha=71.194(4)^{\circ}, \beta=$ $72.412(4)^{\circ}, \gamma=71.451(4)^{\circ}, 100(2) \mathrm{K}, V=1457.6(1) \AA^{3}, Z=2.15053$ reflections measured, 5054 independent (Rint $=0.0280) . R_{1}=0.0316, \mathrm{w} R_{2}=0.868$ (all data)

[17] This fact has been previously found in our group for rhenium I carbonyl complexes, see reference $13 \mathrm{~b}$

[18] Selected crystallographic data for 8b: $\mathrm{C}_{61} \mathrm{H}_{43} \mathrm{BF}_{24} \mathrm{MoN}_{4} \mathrm{O}_{2}, M=1426.74$, othorhombic, Pbca, $a=20.731(4) \AA, b=17.889(3) \AA, c=32.348(7) \AA, \alpha=$ $90.0^{\circ}, \beta=90.0^{\circ}, \gamma=90.0^{\circ}, 100.0(1) \mathrm{K}, V=11997(4) \AA^{3}, Z=8.11804$ reflections measured, 11804 independent $($ Rint $=0.1566) . R_{1}=0.0474 \mathrm{w} R_{2}=$ 0.1157 (all data)

[19] Selected crystallographic data for 9: $\mathrm{C}_{22} \mathrm{H}_{22} \mathrm{MoN}_{4} \mathrm{O}_{2}, M=470.38$, monoclinic, $\mathrm{P} 21 / \mathrm{m}, a=7.7629(7) \AA, b=11.3558(10) \AA, c=14.5788(12) \AA, \alpha=90.0^{\circ}, \beta=$ $90.671(3)^{\circ}, \gamma=90.0^{\circ}, 100(2) \mathrm{K}, V=1285.1(2) \AA^{3}, Z=4.18707$ reflections measured, 2572 independent $(\mathrm{Rint}=0.0462) . R_{1}=0.0467, \mathrm{w} R_{2}=0.1376$ (all data).

[20] G. Sini, O. Eisenstein, R. H. Crabtree, Inorg. Chem. 2002, 41, 602-604.

[21] The $\mathrm{C}_{\text {carbene }}-\mathrm{P}$ coupling in ${ }^{13} \mathrm{C}$ NMR data of trans- $\left[\mathrm{Au}(\mathrm{NHC})\left(\mathrm{PR}_{3}\right)\right]$ compounds has been reported only in a few instances, and have shown a similar coupling constant value. See for example: a) C. Radloff, J. J. Weigand, F. E. Hahn, Dalton Trans. 2009, 9392-9394; b) S. Gaillard, P. Nun, A. M. Z. Slawin, S. P. Nolan, Organometallics 2010, 29, 5402-5408.

[22] Selected crystallographic data for 10: $\mathrm{C}_{40} \mathrm{H}_{37} \mathrm{AuCl}_{2} \mathrm{~F}_{3} \mathrm{MoN}_{4} \mathrm{O}_{5} \mathrm{PS}, M=1137.57$, monoclinic, P2(1), $a=8.1515(5) \AA, b=30.2575(14) \AA, c=16.9305(10) \AA, \alpha=$ $90.0^{\circ}, \beta=91.331(3)^{\circ}, \gamma=90.0^{\circ}, 100.0(1) \mathrm{K}, V=4174.7(4) \AA^{3}, Z=4.16447$ reflections measured, 16410 independent $($ Rint $=0.0462) . R_{1}=0.0530, \mathrm{w} R_{2}=$ 0.1053 (all data).

[23] a) C. Böhler, D. Stein, N. Donati, H. Grützmacher, New J. Chem. 2002, 26 , 1291-1295; b) M. V. Baker, P. J. Barnard, S. J. Berners-Price, S. K. Brayshaw, J. L. Hickey, B. W. Skelton, A. H. White, J. Organomet. Chem. 2005, 690, 56255635 . 
[24] See reference $21 \mathrm{~b}$ and references therein.

[25] E. Gómez, M. A. Huertos, J. Pérez, L. Riera, A. Menéndez-Velázquez, Inorg Chem. 2010, 49, 9527-9534.

[26] M. A. Huertos, J. Pérez, L. Riera, J. Díaz, R. López, Angew. Chem. Int. Ed. 2010 49, 6409-6412.

[27] E. Clementi, D. L. Raimondi, W. P. Reinhardt, J. Chem. Phys. 1967, 47,13001307

[28] B. J. Brisdon, G. F. Griffin, J. Chem. Soc., Dalton Trans. 1975, 1999-2002.

[29] R. Usón, A. Laguna, M. Laguna, Inorg. Synth. 1989, 26, 85-91.

[30] A. A. Gridnev, I. M. Mihaltseva, Synth. Commun. 1994, 24, 1547-1555.

[31] M. Brookhart, B. Grant, A. F. Volpe Jr., Organometallics 1992, 11, 3920-3922.

[32] APPEX II; Bruker AXS Inc.; Madison, WI, USA, 2004.

[33] G. M. Sheldrick. SHELX-97 (SHELXS 97 and SHELXL 97), Programs for Crystal Structure Analyses; University of Göttingen: Göttingen (Germany), 1996.

[34] Crysalis ${ }^{\text {Pro }}$ CCD, CrysAlis ${ }^{\text {Pro }}$ RED. Oxford Diffraction Ltd., Abingdon, Oxfordshire, UK

[35] A. Altomare, G. L. Cascarano, C. Giacovazzo, A. Guagliardi, M. C. Burla, G. Polidori, M. Camalli, J. Appl. Cryst. 1994, 27, 435.

[36] A. Altomare, M. C. Burla, M. Camalli, G. L. Cascarano, C. Giacovazzo, A. Guagliardi, A. G. G. Moliterni, G. Polidori, R. Spagna, J. Appl. Cryst. 1999, 32, 115 .

[37] G. M. Sheldrick, Acta Cryst. 2008, A64, 112.

[38] L. J. Farrugia, , J. Appl. Cryst. 1997, 30, 565.

[39] M. J. Frisch, G. W. Trucks, H. B. Schlegel, G. E. Scuseria, M. A. Robb, J. R. Cheeseman, J. A. Montgomery, J. T. Vreven, K. N. Kudin, J. C. Burant, J. M. Millam, S. S. Iyengar, J. Tomasi, V. Barone, B. Mennucci, M. Cossi, G. Scalmani, N. Rega, G. A. Petersson, H. Nakatsuji, M. Hada, M. Ehara, K. Toyota, R. Fukuda, J. Hasegawa, M. Ishida, T. Nakajima, Y. Honda, O. Kitao, H. Nakai, M. Klene, X. Li, J. E. Knox, H. P. Hratchian, J. B. Cross, C. Adamo, J. Jaramillo, R. Gomperts, R. E. Stratmann, O. Yazyev, A. J. Austin, R. Cammi, C. Pomelli, J. W. Ochterski, P. Y. Ayala, K. Morokuma, G. A. Voth, P. Salvador, J. J. Dannenberg, V. G. Zakrzewski, S. Dapprich, A. D. Daniels, M. C. Strain, O. Farkas, D. K. Malick, A. D. Rabuck, K. Raghavachari, J. B. Foresman, J. V. Ortiz, Q. Cui, A. G. Baboul, S. Clifford, J. Cioslowski, B. B. Stefanov, G. Liu, A. Liashenko, P. Piskorz, I. Komaromi, R. L. Martin, D. J. Fox, T. Keith, M. A. Al-Laham, C. Y. Peng, A. Nanayakkara, M. Challacombe, P. M. W. Gill, B. Johnson, W. Chen, M. W. Wong, C. Gonzalez, J. A. Pople, Gaussian 03, Revision C.02, Gaussian, Inc.: Wallingford, CT, 2004.

[40] a) A. D. Becke, Phys. Rev. A 1988, 38, 3098-3100; b) C. Lee, W. Yang, R. G. Parr, Phys. Rev. B 1988, 37, 785-789; c) A. D. Becke, J. Chem. Phys. 1993, 98, 5648-5652.

[41] W. J. Hehre, L. Radom, J. A. Pople, P. v. R. Schleyer, Ab Initio Molecular Orbital Theory, Wiley, New York, 1986.

[42] J. Hay, W. R. Wadt, J. Chem. Phys. 1985, 82, 299-310.

[43] H. B. Schlegel, J. Comput. Chem. 1982, 3, 214-218.

[44] a) C. Gonzalez, H. B. Schlegel, J. Phys. Chem. 1989, 90, 2154-2161; b) C. Gonzalez, H. B. Schlegel, J. Phys. Chem. 1990, 94, 5523-5527.
[45] D. A. McQuarrie, Statistical Mechanics, Harper and Row, New York, 1976

[46] a) V. Barone, M. Cossi, J. Phys. Chem. A 1998, 102, 1995-2001; b) M. Cossi, N. Rega, G. Scalmani, V. Barone, J. Comput. Chem. 2003, 24, 669-681; c) V. Barone, M. Cossi, J. Tomasi, 1997, 107, 3210-3221.

[47] a) E. Reed, L. A. Curtiss, F. Weinhold, Chem. Rev. 1988, 88, 899-926; b) F. Weinhold, J. E. Carpenter in The Structure of Small Molecules and Ions, Vol. Eds.: R. Naaman and Z. Vager), New York, 1988.

[48] J. P. Perdew, K. Burke, M. Ernzerhof, Phys. Rev. Lett. 1996, 77, 3865-3869.

[49] a) A. D. Becke, Phys. Rev. A 1988, 38, 3098-3102; b) A. D. Becke, J. Chem. Phys. 1996, 104, 1040-1047.

[50] J. Tao, J. P. Perdew, V. N. Staroverov, G. E. Scuseria, Phys. Rev. Lett. 2003, 91 , 146401-146404.

[51] C. Lee, W. Yang, R. G. Parr, Phys. Rev. B 1988, 37, 785-789.

[52] a) V. N. Staroverov, G. E. Scuseria, J. Tao, J. P. Perdew, J. Chem.Phys. 2003, 119, 12129-12137; b) V. N. Staroverov, G. E. Scuseria, J. Tao, J. P. Perdew, J. Chem. Phys. 2004, 121, 11507, Erratum.

[53] A. D. Boese, J. M. L. Martin, J. Chem. Phys. 2004, 121, 3405-3416.

[54] Y. Zhao, D. G. Truhlar, Theor. Chem. Acc. 2008, 120, 215-241.

[55] M. J. Frisch, G. W. Trucks, H. B. Schlegel, G. E. Scuseria, M. A. Robb, J. R. Cheeseman, G. Scalmani, V. Barone, B. Mennucci, G. A. Petersson, H. Nakatsuji, M. Caricato, X. Li, H. P. Hratchian, A. F. Izmaylov, J. Bloino, G. Zheng, J. L. Sonnenberg, M. Hada, M. Ehara, K. Toyota, R. Fukuda, J. Hasegawa, M. Ishida, T. Nakajima, Y. Honda, O. Kitao, H. Nakai, T. Vreven, J. A. Montgomery, Jr., J. E. Peralta, F. Ogliaro, M. Bearpark, J. J. Heyd, E. Brothers, K. N. Kudin, V. N. Staroverov, R. Kobayashi, J. Normand, K. Raghavachari, A. Rendell, J. C. Burant, S. S. Iyengar, J. Tomasi, M. Cossi, N. Rega, J. M. Millam, M. Klene, J. E. Knox, J. B. Cross, V. Bakken, C. Adamo, J. Jaramillo, R. Gomperts, R. E. Stratmann, O. Yazyev, A. J. Austin, R. Cammi, C. Pomelli, J. W. Ochterski, R. L. Martin, K. Morokuma, V. G. Zakrzewski, G. A. Voth, P. Salvador, J. J. Dannenberg, S. Dapprich, A. D. Daniels, Ö. Farkas, J. B. Foresman, J. V. Ortiz, J. Cioslowski, and D. J. Fox, Gaussian 09, Revision A.1, Gaussian, Inc., Wallingford CT, 2009.

Received: ((will be filled in by the editorial staff))

Revised: ((will be filled in by the editorial staff)) Published online: ((will be filled in by the editorial staff)) 
Entry for the Table of Contents (Please choose one layout only)

Discordant mechanisms explained

Marcel Brill, Jesús Díaz*, Miguel A. Huertos, Ramón López*, Julio

Pérez, and Lucía Riera*.

Page - Page

\section{Imidazole to NHC}

rearrangements at molybdenum centers. An experimental and theoretical study

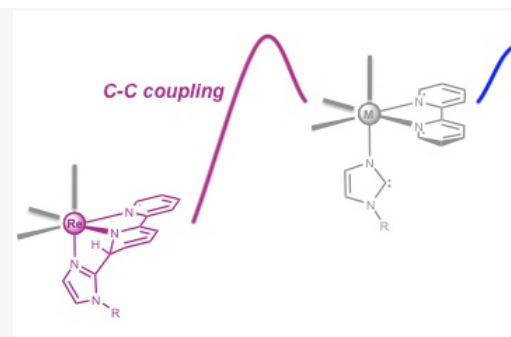

Deprotonation of coordinated imidazoles: a garden of forking paths. DFT computations at the B3LYP/6-31G(d) (LANL2DZ for $\mathrm{Mn}, \mathrm{Re}$, and Mo) level of theory explain the different behavior experimentally found for the deprotonation of $\left[\mathrm{M}(\right.$ bipy $)(\mathrm{CO})_{3}(\mathrm{~N}$ $\mathrm{RIm})]^{+}(\mathrm{M}=\mathrm{Mn}, \mathrm{Re})$ complexes. $\left[\mathrm{Mo}\left(\eta^{3} \text {-allyl }\right)(\text { bipy })(\mathrm{CO})_{2}(N-\mathrm{R} \operatorname{Im})\right]^{+}$ species have shown, both experimental and teoretically, a reactivity pattern analogous to that of Mn, suggesting that an unexpected mechanism that involves a CO ligand can be quite general for this type of transformation. 